Bull. Fac. Agric., Cairo Univ., 70: 291-306 (2019).

\title{
ATTITUDES OF FARMERS IN RECLAIMED AREAS TOWARDS SOCIAL INSURANCE IN THE NEW VALLEY GOVERNORATE
}

(Received: 24.12.2019)

\author{
By \\ H. G. Shaban \\ Department of Social Studies - Desert Research Center, Cairo, Egypt
}

\begin{abstract}
Search target:

- Knowing the attitudes of farmers in the reclaimed areas towards the Social Insurance Law Knowing the sources of farmers information about social insurance.

- Knowing the positives involved in the social insurance system in the Arab Republic of Egypt to highlight and support them.

- Determine the obstacles that limit the efficiency and effectiveness of the social insurance system in achieving safety and social protection for farmers and their families

- Knowing the opinion of the respondents about the proposals to increase the role of social security development.

- Determine the significance of the relationship between the personal variables of the respondents, which are the participants, the beneficiaries, the non-subscribers, and their attitudes towards social insurance.

- To come up with a set of results and recommendations that could form the basis for building strategies to improve the efficiency and effectiveness of the social insurance system in the Arab Republic of Egypt.
\end{abstract}

This study was conducted in the New Valley Governorate (Kharga-Paris- Balat-Mut -Al-Qasr ).

The total size reached 24057 farmers, the sample size is 378 respondents, which represents $1.57 \%$ according to the Krejsi and Marjan equation, which is a random sample of participants, beneficiaries, and non-subscribers to the social insurance system, distributed as follows: 126 respondents under the age of 60 participants in social insurance, 126 respondents over the age of 60 beneficiaries (pensioners) ), 126 respondents under the age of 60 not covered by social insurance.

The data were collected in the interviewer's personal interviews with the respondents by means of a questionnaire designed for this purpose during the months of July and September 2019, and the researcher used to tabulate the data and analyze the tables of numerical inventory, percentages and convergence coefficient (Ka2), and the simple correlation coefficient. The most important results were as follows: For a description ,the research sample subscribers to social insurance that more than twothirds of the sample were males and their rate is $67.5 \%$, more than two-thirds of the sample were aged between 20 to less than 40 where their percentage was $68.3 \%$, half of the respondents were from medium qualifications holders, and More than two thirds of the individuals Sample working Employees government next to their work as farmers and an and their rate is $66.7 \%$, and that the majority of respondents were married and accounting for $91.3 \%$, that more than half of the sample size of the farm from 1 to less than 5 tenure Ovdanh and accounting for $58.7 \%$

Regarding the respondents' orientation towards social insurance, the results show the following:

- More than half of the respondents (54.76\%) who participate in the social insurance system have a positive trend towards it, and the percentage of respondents who benefited in the positive direction category has converged to $46,83 \%$, while the percentage of respondents who are not subscribers has decreased to $15,08 \%$

- There is a relationship between all variables studied type, profession, educational qualification, marital status, ownership of small projects, age and income, and the attitudes of the joint respondents towards social security. The value of the Chi square reached 53,993, 102,488, $163,867,50,912,48,540$, respectively, which is greater than its tabular counterpart. The value of the 
simple correlation coefficient for age and income was 338 and 816, respectively which is greater than its tabular counterpart

- There was no significant correlation between the variables of the number of family members, the size of possession for the joint respondents and their attitudes towards social insurance, as the value of the simple correlation coefficient calculated -113 and -049 , respectively, which is less than its tabular counterpart.

Key words : attitudes - reclaimed areas - social insurance

إتجاهات المزارعين بالمناطق المستصلحة نحو التامينات الإجتماعية بمحافظة الوادى الجديد

\author{
حسن جلال شعبان \\ قسم الدراسات الإجتماعية - مركز بحوث الصحراء - العطرية ـ القاهرة
}

ملخص

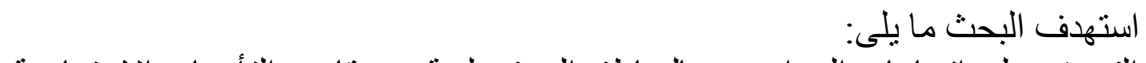

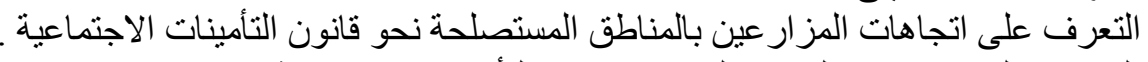

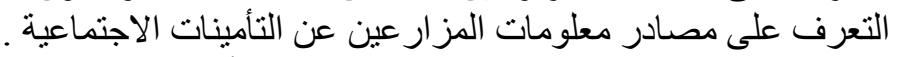

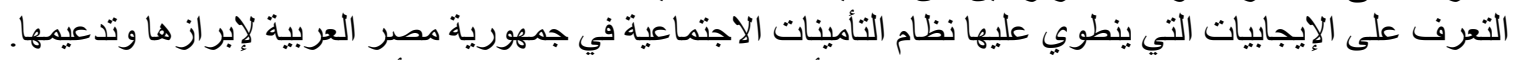

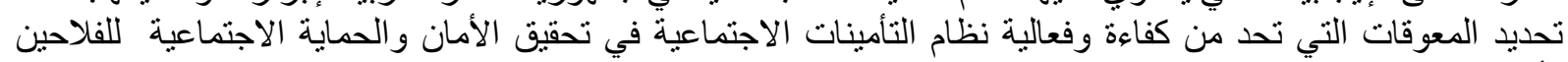

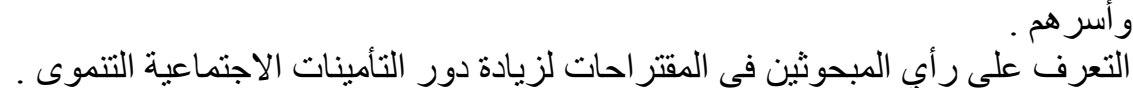

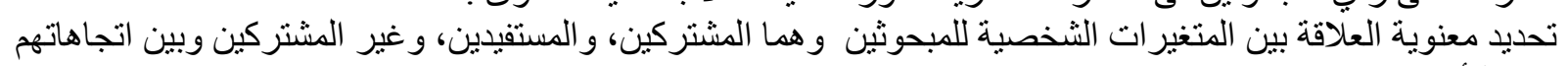

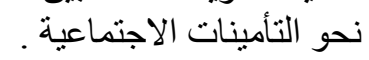
الخروج بمجمو عة من النتائج و التوصيات التهي من التهاع الممكن أن تشكل أساسًا لبناء استر اتيجيات لتحسين كفاءة وفعالية نظام

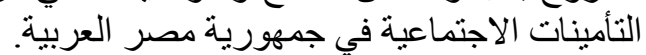

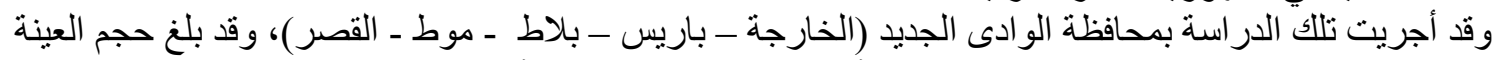

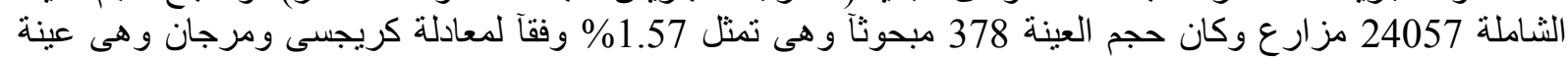

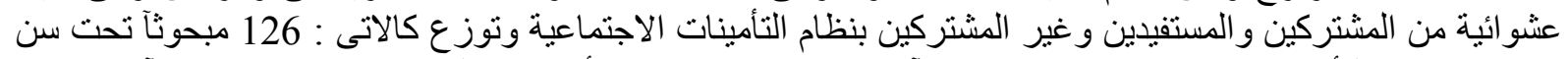

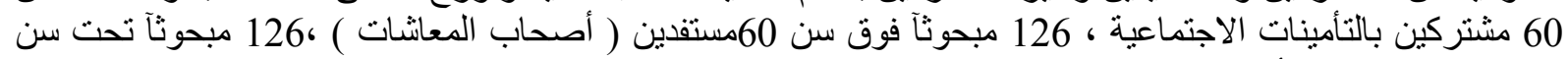
60 غير مشتركين بالتأمينات الاجتماعية 60

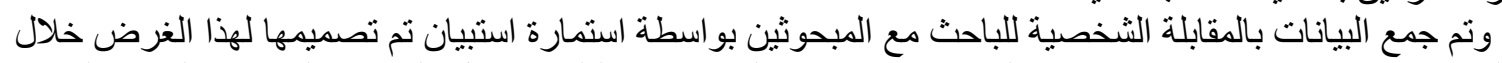

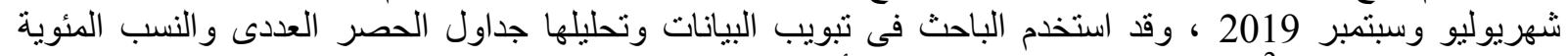

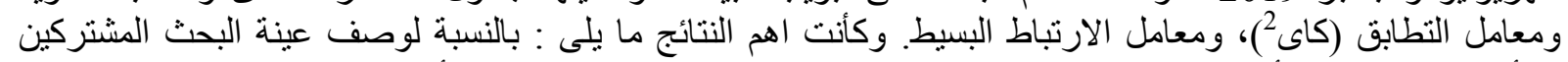

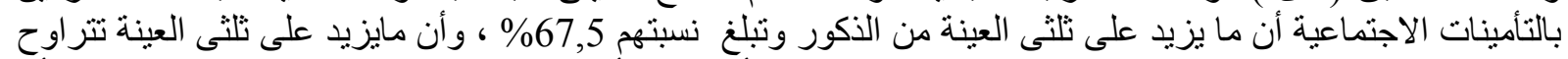

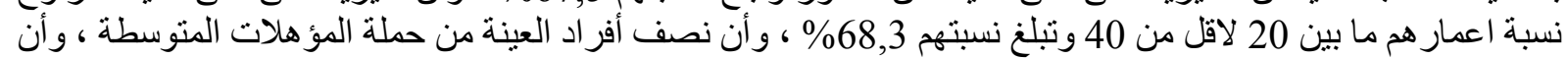

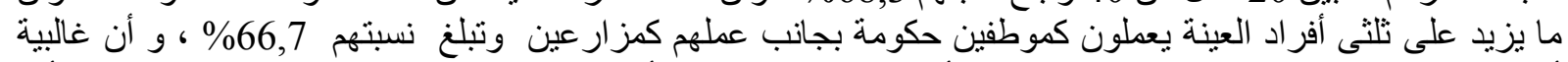

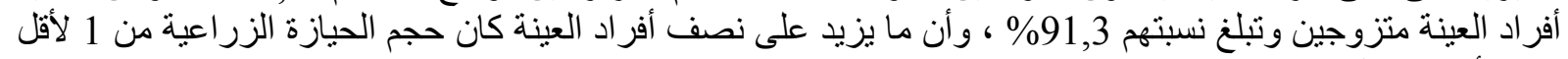

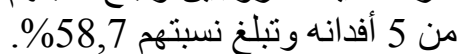

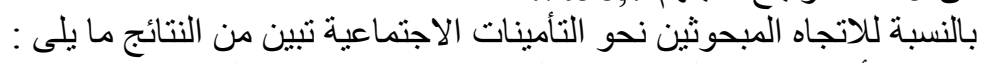

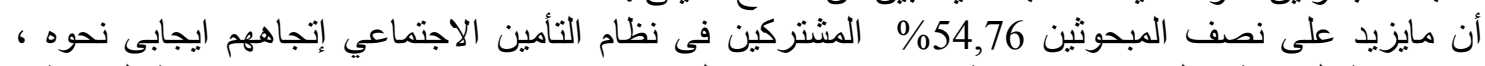
وتقاربت منها نسبة المبحوثين المستفيدين فى فئة الاتجاه الايجابى وبلغت

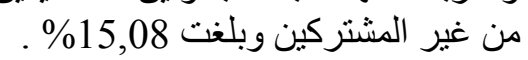

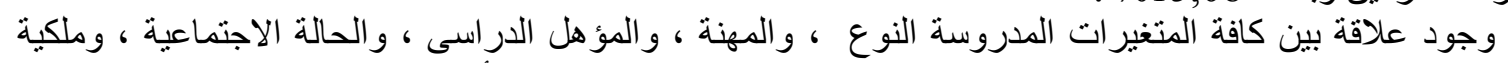

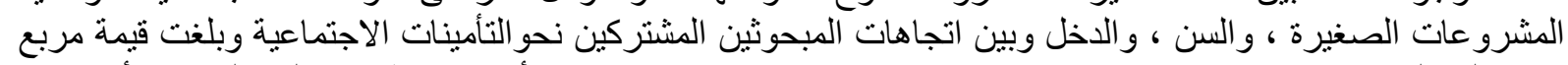

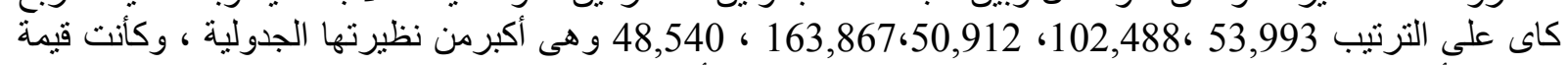

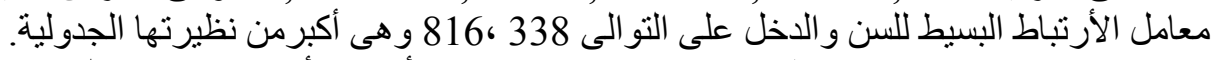

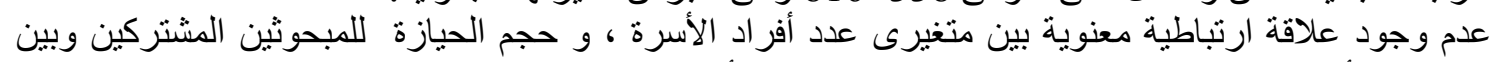

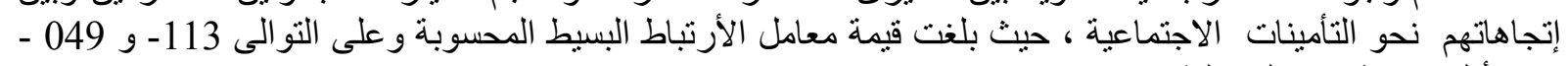
وهى أقل من نظيرتها الجدولية. 
له، و على قدرثه المالية على الوفاء بالتز اماته المستقبلية. يهدف البحث تقديم بعض الإلى الاقتر احات التي تسهم في

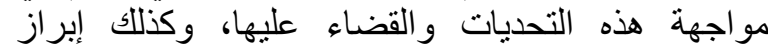

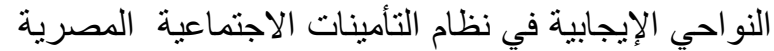

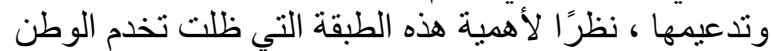

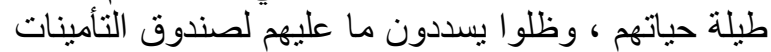

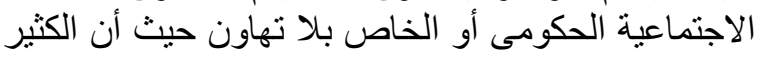

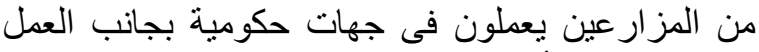

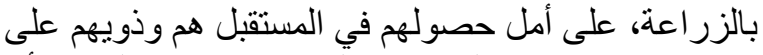

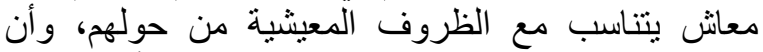

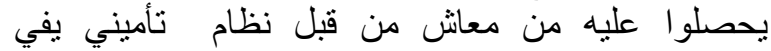
بالاحتياجات الضرورية التي تمكنهم من الحياة الكريمة.

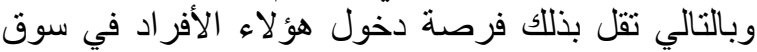

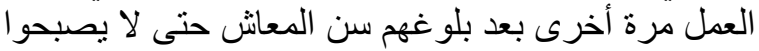

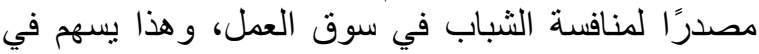

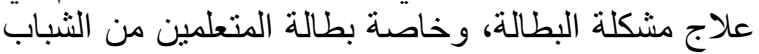

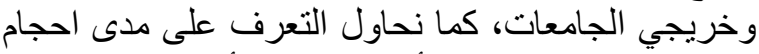
المزارع المصرى عن الأشتر اك فى التأمينات الاجتماعية التهاية

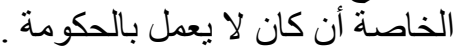

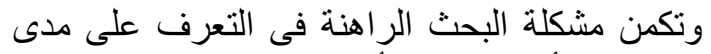

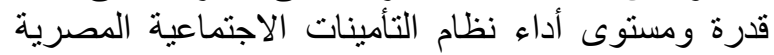

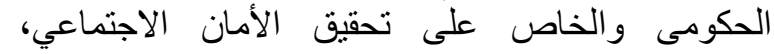

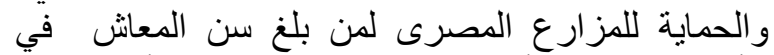

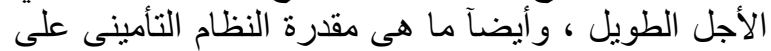

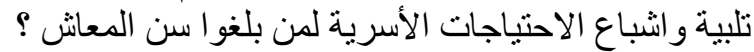

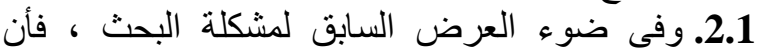
التساؤل الرئيسى لهذ البحث مؤداه:

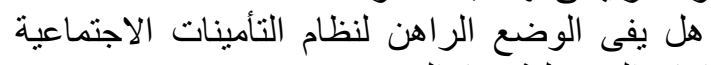

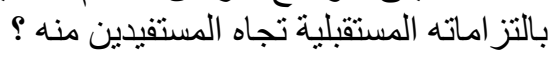

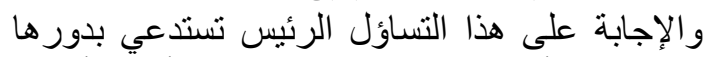

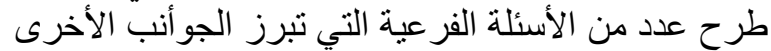

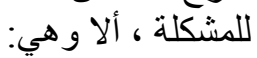
ما هى اتجاهات المزارعين بالمناطق المستصلحة نحو قانون التأمينات الاجتماعية ؟ العزات

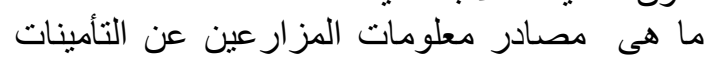
الاجنماعية ؟ إن

ما هى الإيجابيات التي ينطوي عليهاعيا نظام التأمينات الاجتماعية في جمهورية مصر الإيجات العربية ؟ عابها

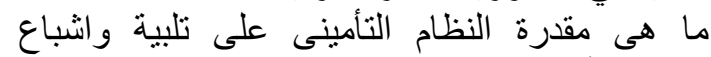

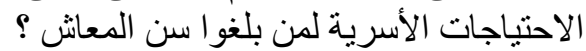

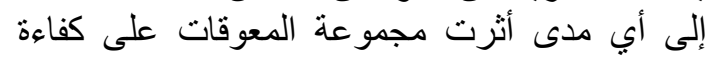
وفعالية نظام التأمينات الاجتماعية في تحقيق الإتي الأمان

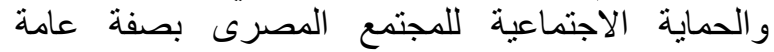

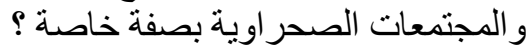
ما هى المقتر احات لزيادة دور التأمينات الاجنماعية بهية التنموى في جمهورية مصر العترات الزيبة ؟

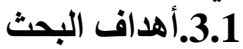

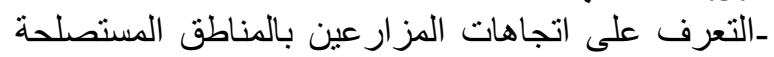
نحو قانون التأمينات الاجتماعية .

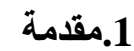

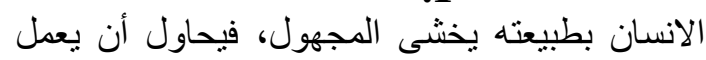

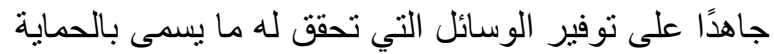

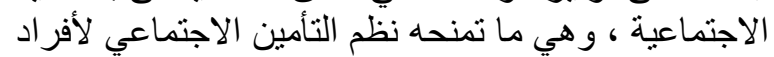

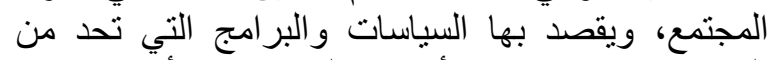

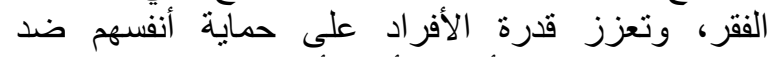
المخاطر التي يسبيها أنقطاع أو فقدأن الأنس الدخل.

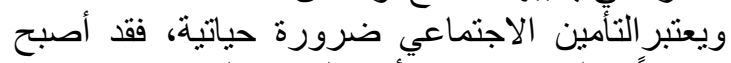

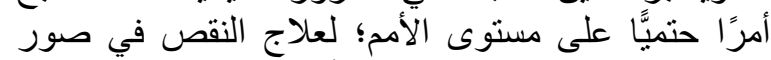

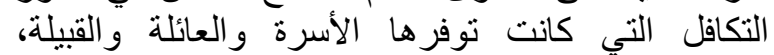

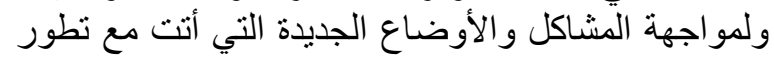

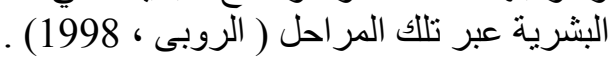

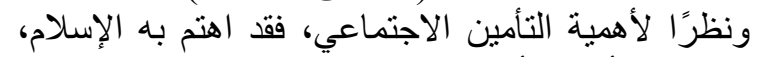

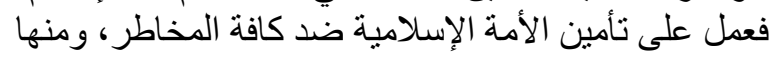

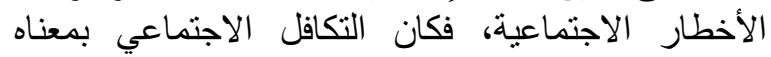

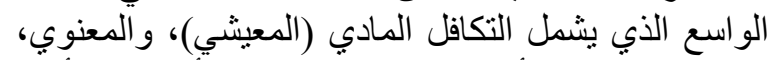

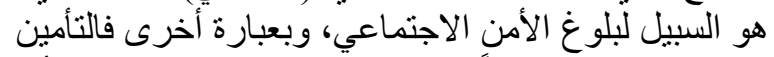

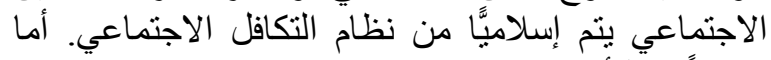

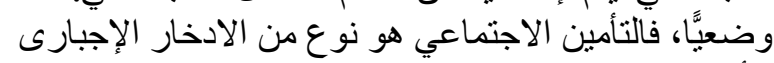

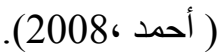
وبالر غم من أن الاتجاهات لها دور ا فعالا ونشطا فى إنى

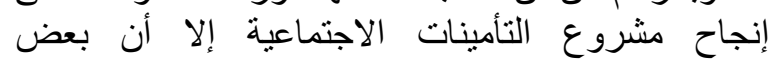

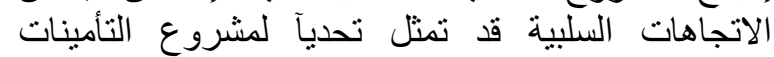

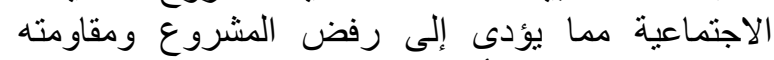
و الحيلولة دون تحقيق أهدافه المبتغاه ـ المبن

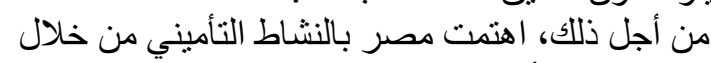

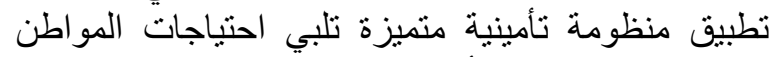

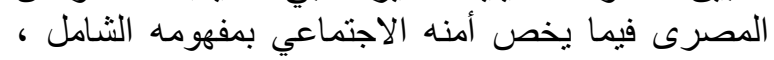

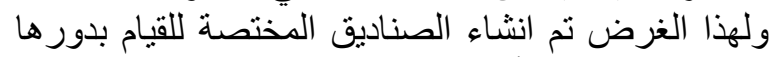

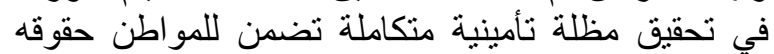

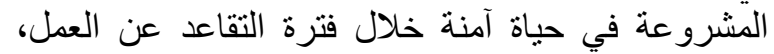

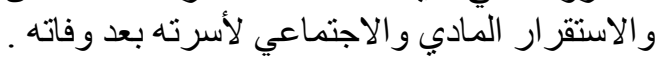

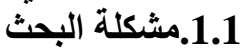

في ضوء اختلاف البحث الاتجاهات ما بين مؤيد

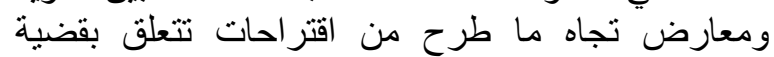

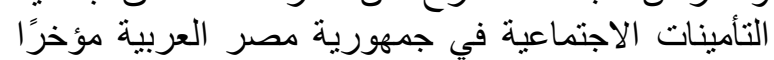

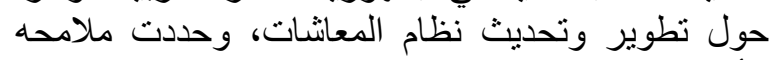

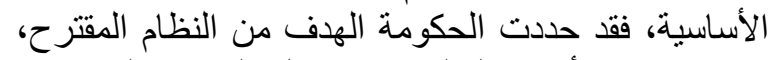

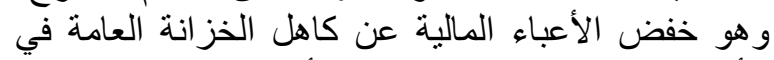

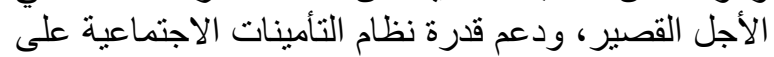

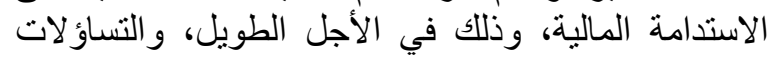

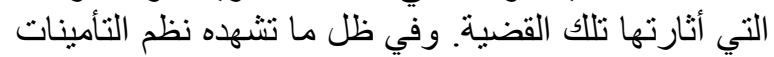

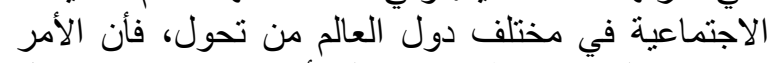

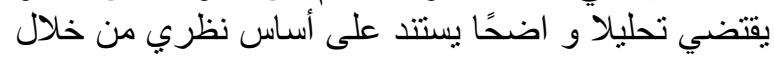

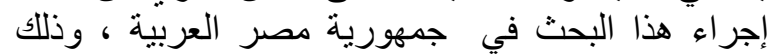

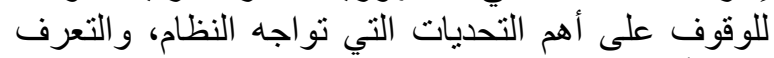

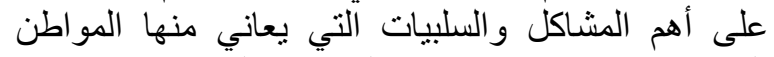

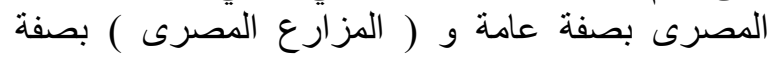
خاصة ، و التي تؤثر سلبًا على الوضع الحالي و المستقبلى ) لـ الح 
بحيث يحل المعاش أو التعويض محل ما يفقده المؤمن عليه من أجر《) ( كامل ، 1999 ) ) . تعريف التأمينات الاجتماعية

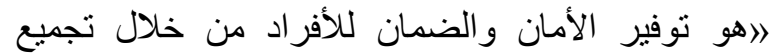

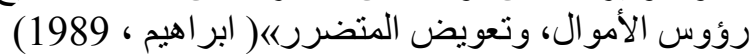

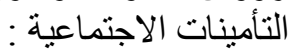

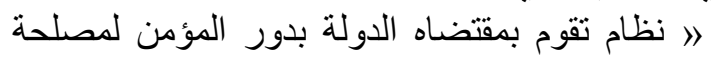

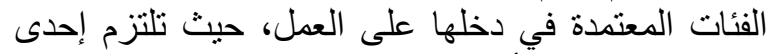

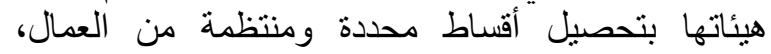

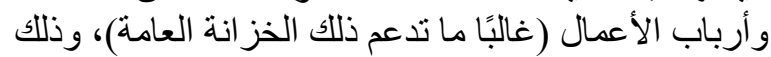

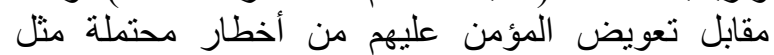

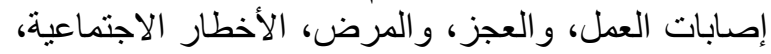

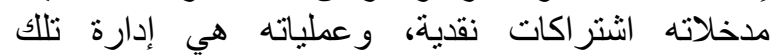
الاشتر اكات، وتوظيفها (تديرها الحكومة، أُ على على الأقل

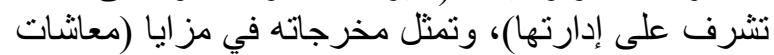

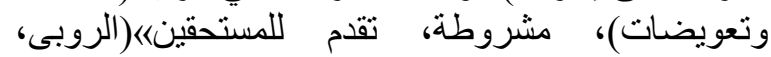

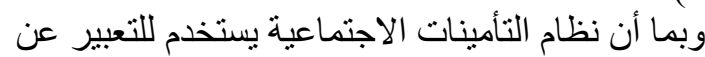

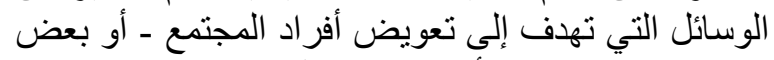

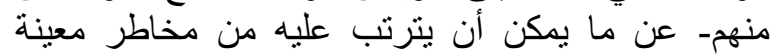

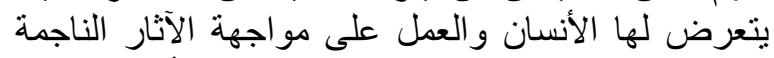

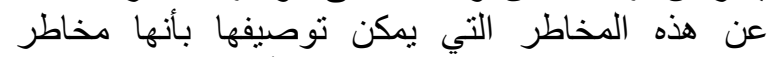

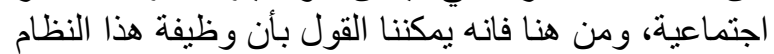

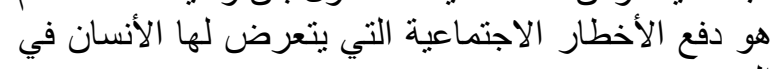

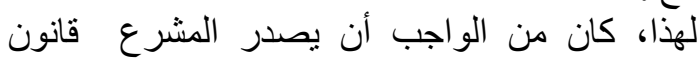

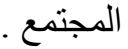

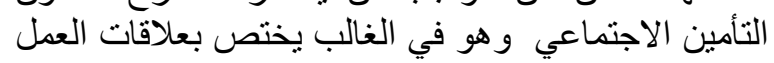

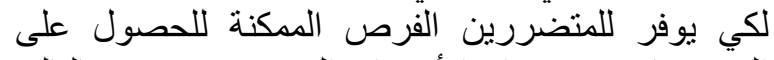

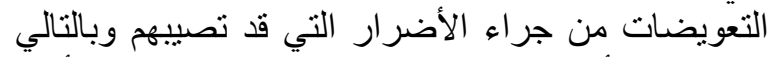

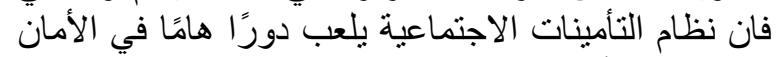
الاجتماعي لأفراد المبنات الإنمع.

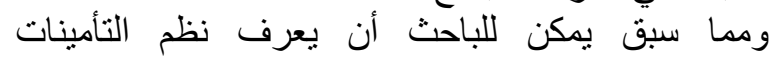

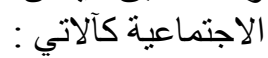

تعريف التأمينات الاجتماعية: لاعلى أنها هي نظام

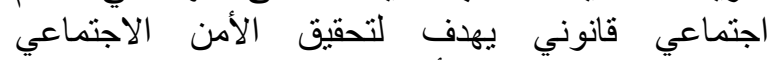

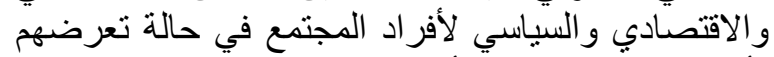

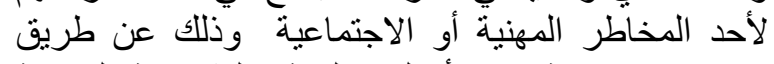

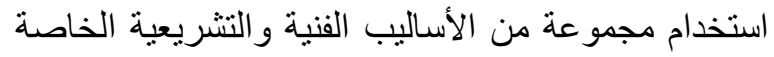

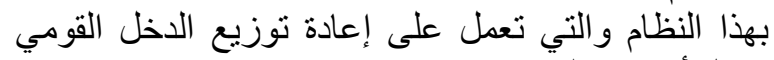

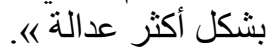

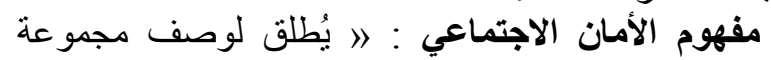

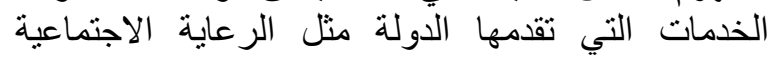

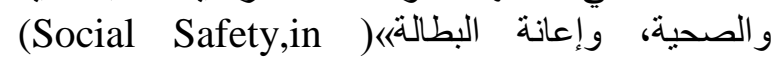
.Wikipedia

ويرى الباحث أن شبكة الأمان الاجتماعي ليست

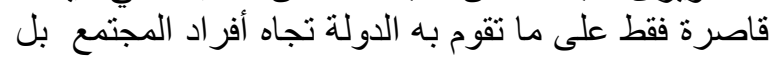

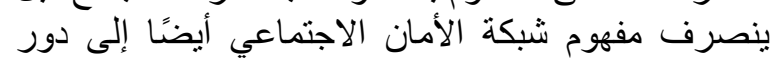
المجتمع المدني من هيئات ومنظمات غئرة الاجير حكومية تجاه

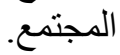

ـالتعرف على مصادر معلومات المزارعين عن التأمينات

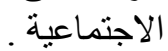

ـالتعرف على الإيجابيات التي ينطوي عليها نظام التأمينات الاجتماعية في جمهورية مصر الإيجيات العربية لإبرازية التانيات

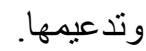

-تحديد المعوقات التي تحد من كفاءة ، وفعالية نظام

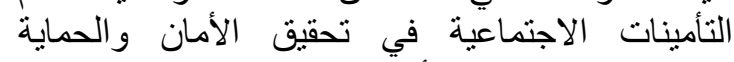
الاجتماعية للفلاحين وأسر هم .

-تحديد العلاقة بين المتغيرات الثين ، الثخصية للمبحوثين وهما

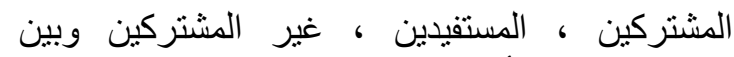
اتجاهاتهم نحو التأمينات الاجتماعية . المينية

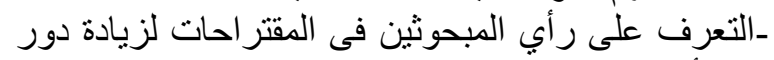

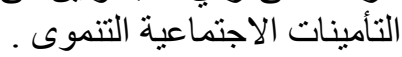

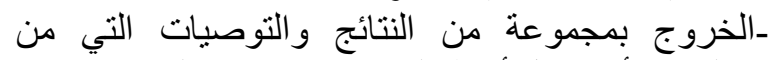

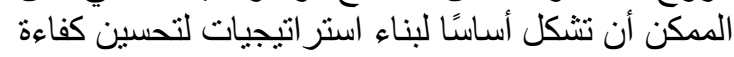

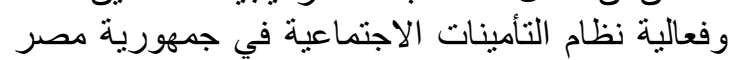
العربية.

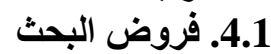

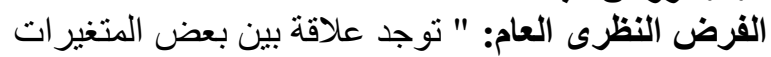

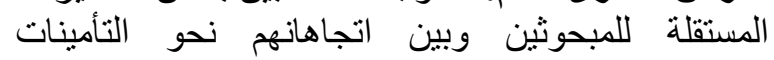
الاجنماعية " المبنة ومن الفرض النظية" النظى العام أمكن وضع الفروض الاحصائية التالية :

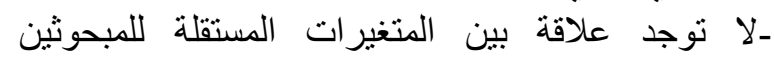

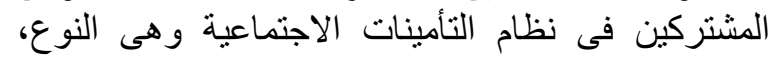

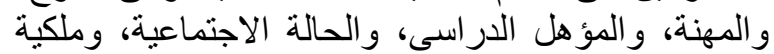

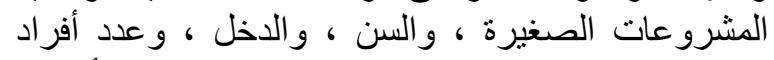

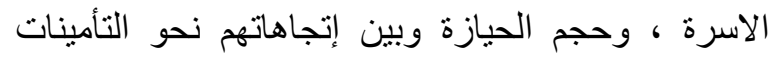

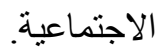
-لا توجد علاقة بين المتغيرات المستقلة للمبحوثين

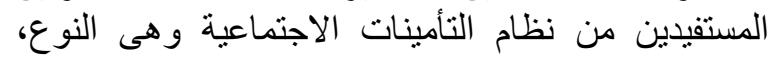

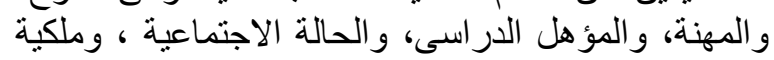

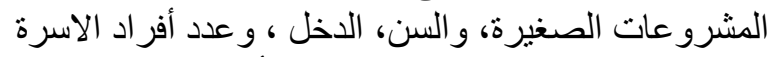

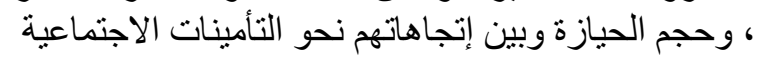

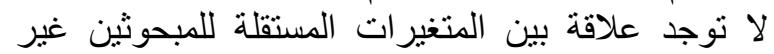

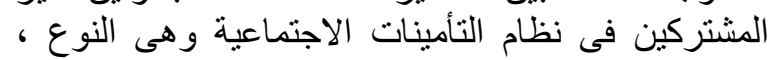

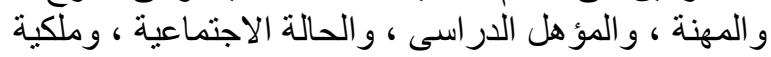

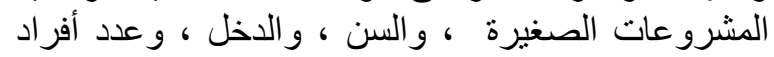

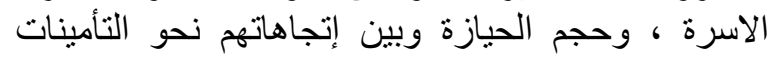

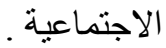

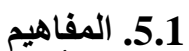

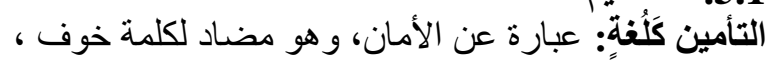

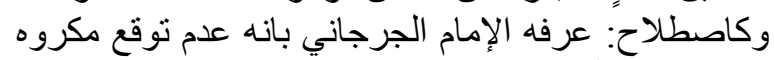

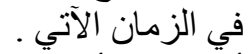
أي : هو الأمان للحياة المستقلية من أبي مخاطر اجتماعية.

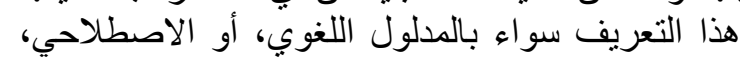

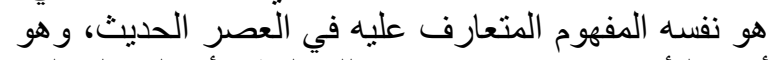

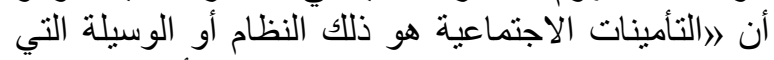
تضمن للفرد الدخل الناتج من نشاطه الحرفي النئ أو المهني 
وفى ضوء هذه هذه العناصر بمكن تعريف الاتجاه تعريفاً

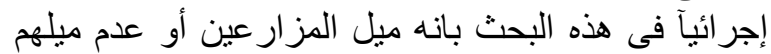

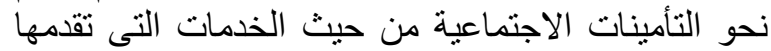
التأمينات الاجتماعية و الامكانات الموجودة لديها و العاملين

هذا ويمكن القول بأن الاتجاهات هى التى قد تدفع

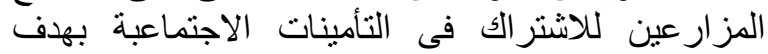

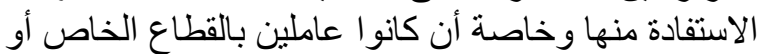
يعملون بالزر اعة فقط.

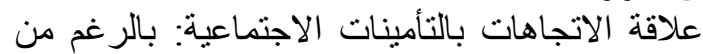

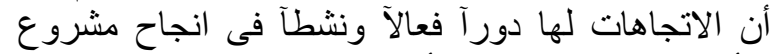

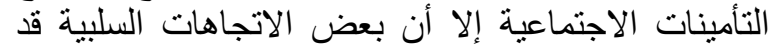

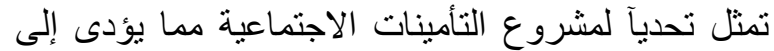
رفض المشروع ومقاومته و الحيلولة دون تحقيق أهدافه التئ

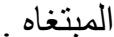

مما سبق يتضح أنه من الضرورى على الإنططين

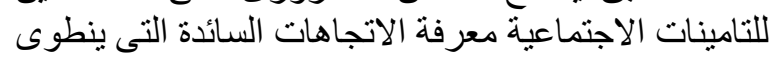

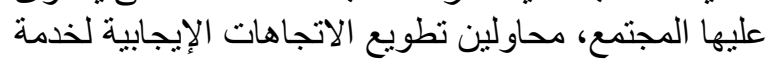
التأمينات الاجتماعية والتعرف على على الاتجاهات الإنات السلبية

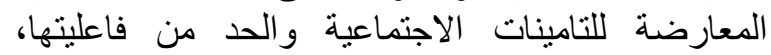

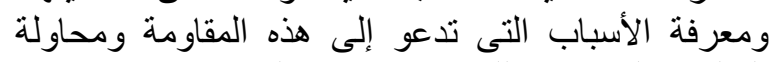
التغلب عليها ، وذلك عن طريق الجدية الإية في تنفيذ هذه

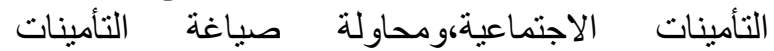

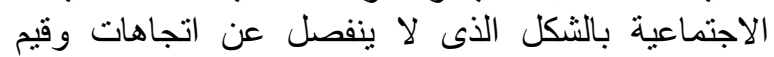

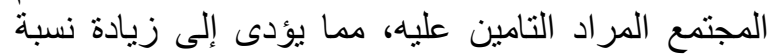

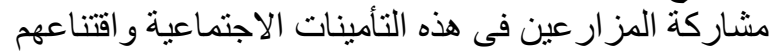

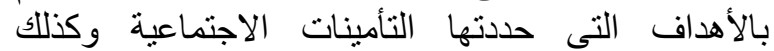

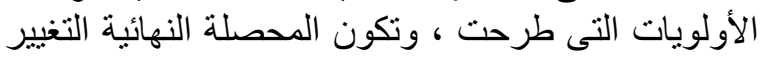

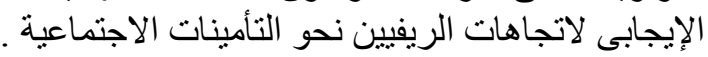

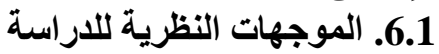
النظريات المفسرة للتأمين الاجتماعي للارلية

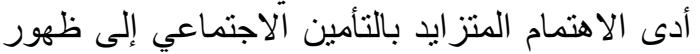

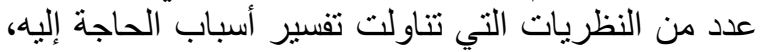

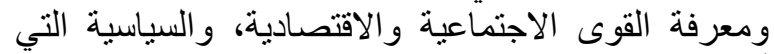

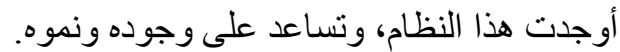

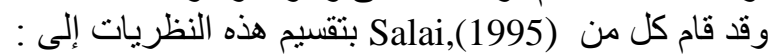
النظريات السياسية، و النظريات القصصية. النظريات السياسية

ترى النظريات السياسية ان النيات تنريع التأمين

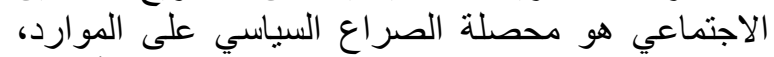

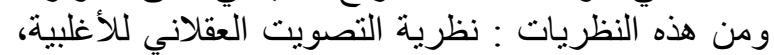

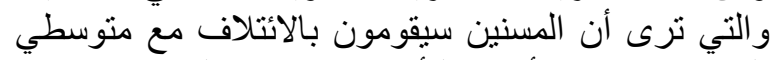

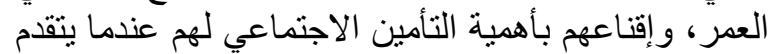

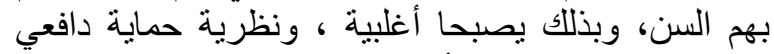

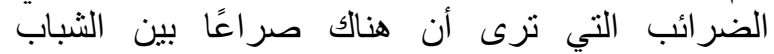

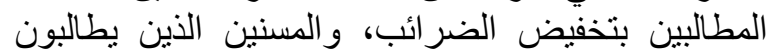

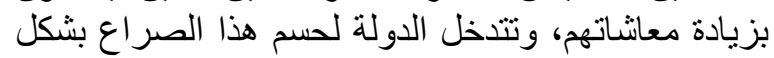

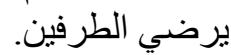
وجدير بالذكر أن أهم ما يميز هذه النظرية هو تناولها

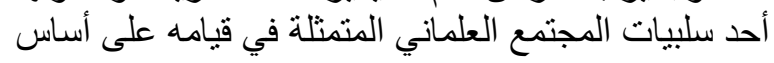

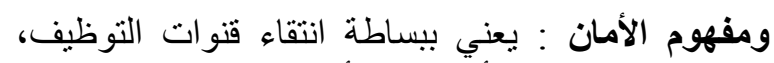

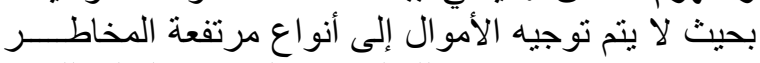
( محمود ، 2007 ) ) ، وذللك لضمان اللئ الديمومة المالية للنظام

ويقصد بالديمومة هنا هو الاستمرارية المالية للنظام

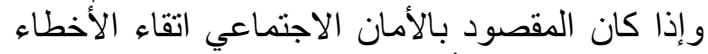

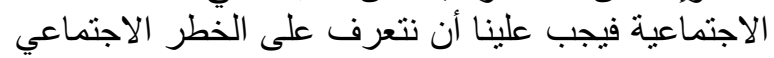

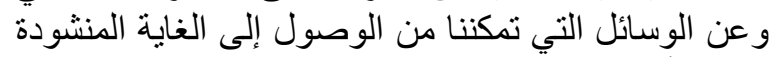

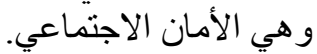

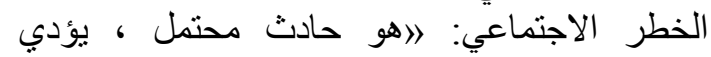

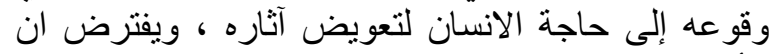

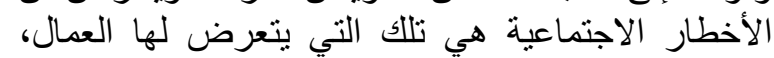

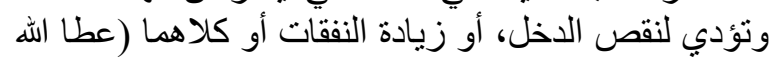

وبالتالي يتم تقسيمها لنو عين كالتالي: الأخطار المهنية، والأخطار الجسمانية الفسيولوجية.

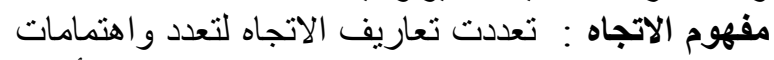

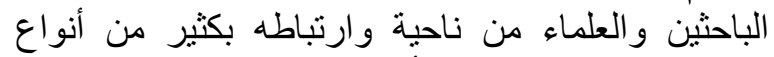

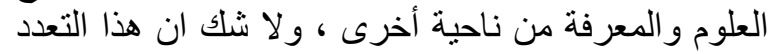

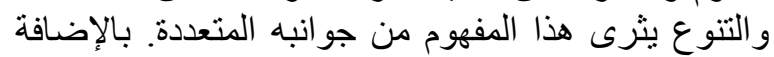
إلى أن هذه التعريفات رغم اختلافهم فى تعريف هذالتها المفهوم، و هذه المحاور هى التعلى التى قد تحدد طبيعة الاتجاه

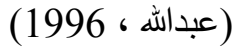
وفيما يلى أهم هذه التعريفات

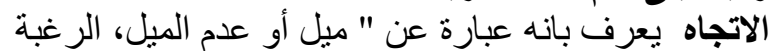

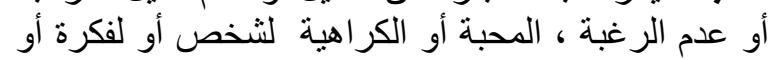

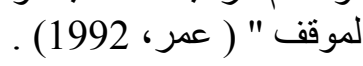
الاتجاه هو استعداد نفسى أو تهيؤ عقلى على عصبى متعلم

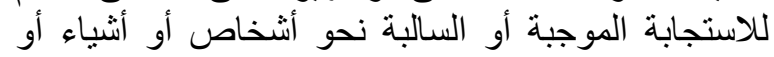

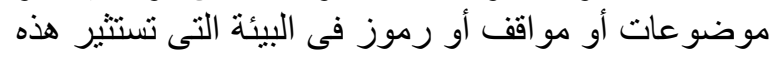
الإستجابة (زهران، الإن 1984 ) ).

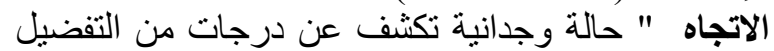

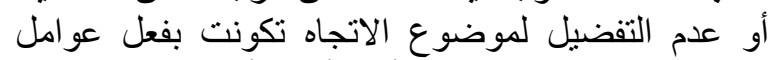

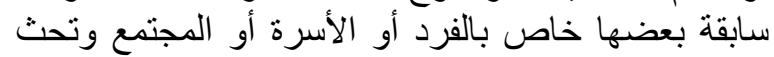

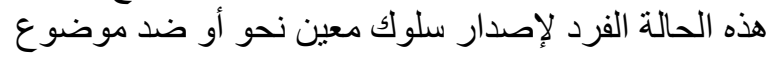

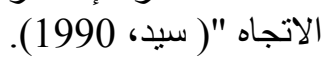

من العرض السابق لتعريفات الاتجاه فانه يمكن التهن استخلاص أهم العناصر الرئيسية التى يرنكز عليفات الانهاه هذا

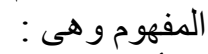
ـ أنه عبارة عن ميل معقد وثابت للاستجابة بطريقة معينة

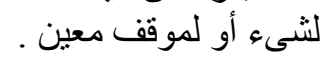
ـ أنه موقف نفسى لفولف لفرد تجاه إحدى القيم و المعايير السائدة في البيئة الاجتماعية. ـ أنه استعداد نفسى أُوتهيؤ عقلى ينتظم عن طريق الخبرة

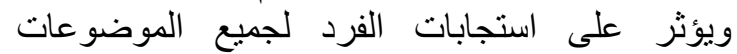

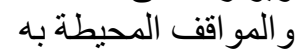
- حالة وجدانية تكثف عن بله درجات من التفضيل أو عدم التفضيل لموضوع النئ نكيف الاتجاه. ـ تقويم سلبى أو إيجابى للأشياء أو للأشخاص أو للأفكار

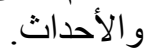


أداؤها و إدر اكها وبناء على الثخصية و النموذج الذي يريد

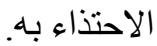

ويقوم الأعضاء المشاركين في انشطة التأمينات الاجتماعية بدور هم بناءً على الوظيفة الاعنة المحددة والمسندة

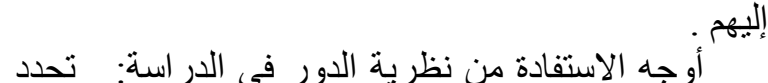

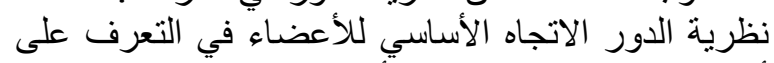

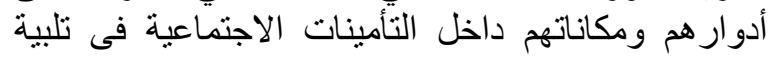

يمكن الاستفادة من نظرية الدور في تحديد المسئوليات

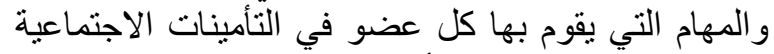
بما يساعدها على تحقيق أهدافها في ظل القيم السائدة في

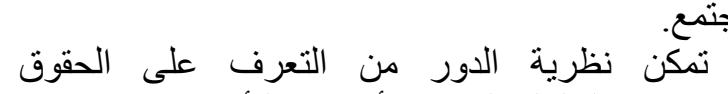
و الو اجبات و السلوك المتوقع لأعضاء التأمينات الاجتماعية

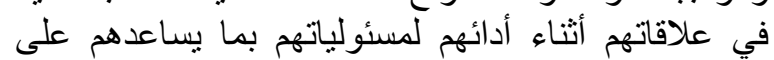
تلبية احتياجاتهم . يمكن للأعضاء المشتركين في الانشطة بالتأمينات

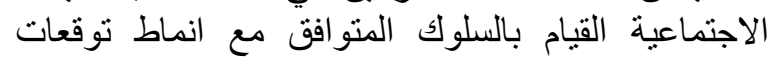

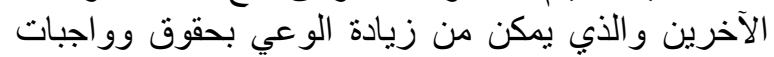

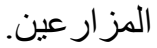

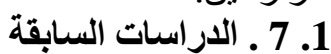

توصلت دراسة بيرنرام سوميرس(عomers,1982) تأثنز الادخار الخاص (الاختياري) سلبًا (علاقة عكسية)

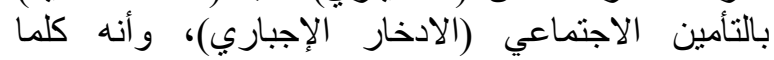

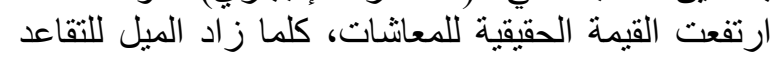

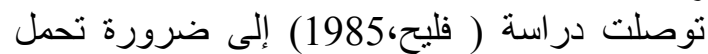

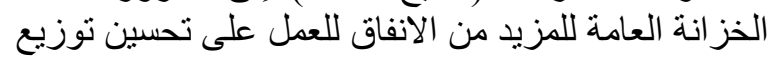

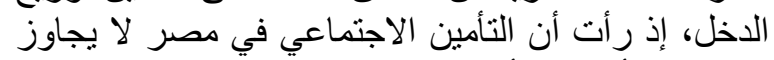

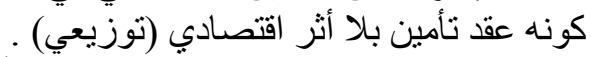

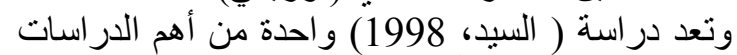

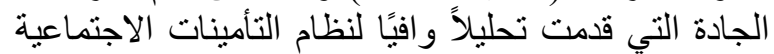

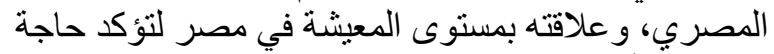

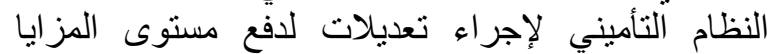
التأمينية التي يقدمها.

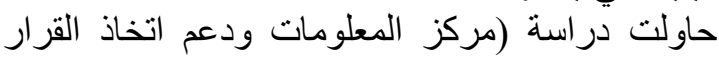

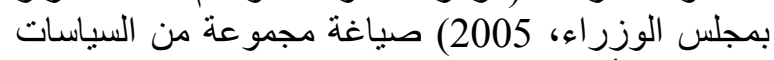

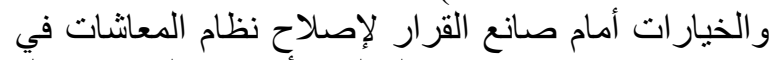

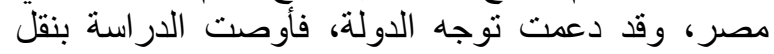

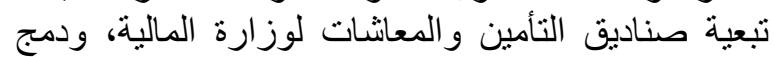

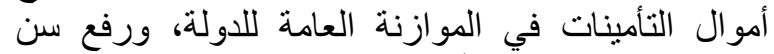

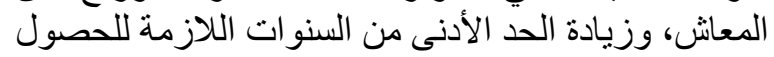

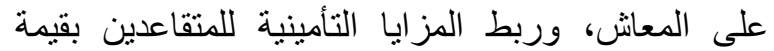
الاشتتر اكات التي يدفعونها.

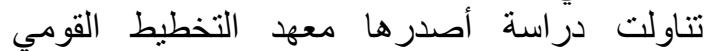

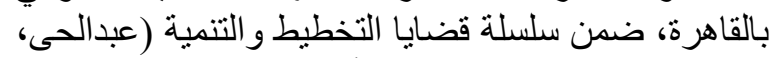

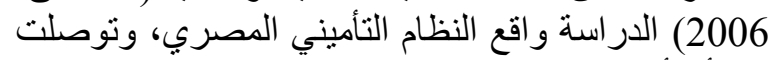

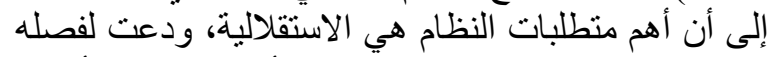
عن وزارة المالية، وإعادة النظر في أوجه استثمار أموال النال
من الصر اع لا التكافل و الرحمة، فضلاً عن تناولها لنظام

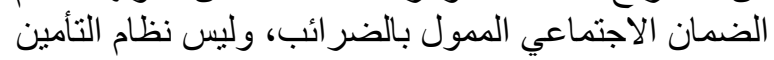
الاجتماعي الممول بالاشتر اكات.

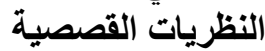

من أبرز هذه النظريات : النظية النظرية التي تهاجم الر أسمالية

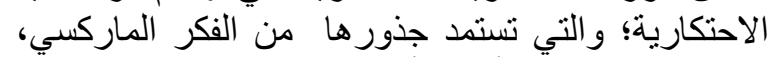

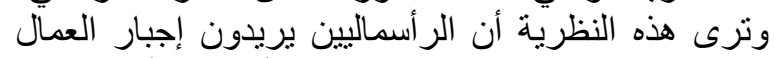

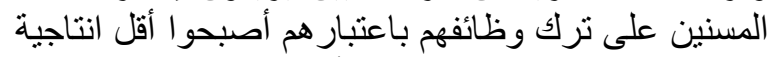
من الثباب، فيضعون نظامًا للتأمين الاجتماعي لاستمالة التالة

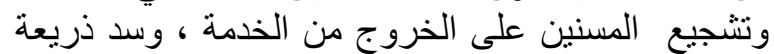
قد تقودهم للقيام بثورة ضد الثن الحكومات الر أسمالية

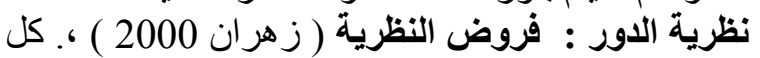

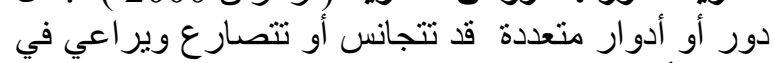

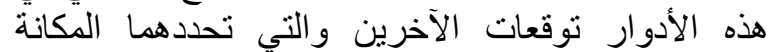
الاجتماعية أو الوضع الاجتوات الأتماعي. يحقق توزيع الأدوار بين أعضاء الأنياء الجماعة وظيفة اجتماعية

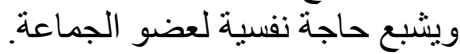

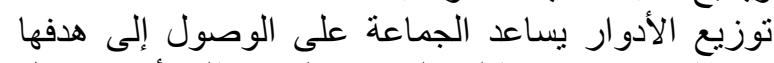

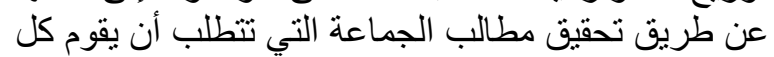

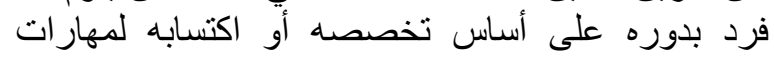

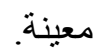

تتوزع الأدوار في نسق معترف به غالبًا من أعضاء

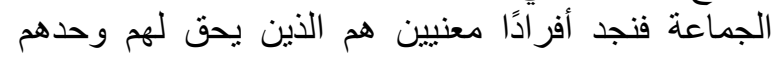

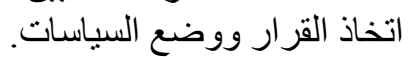
وحيث أن البحثّ الحالي يسعى إلى الى تفعيل دور التأمينات

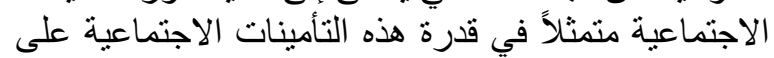

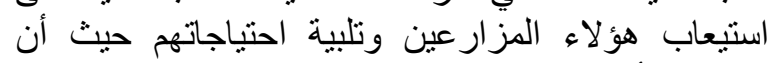

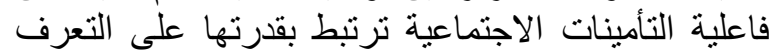

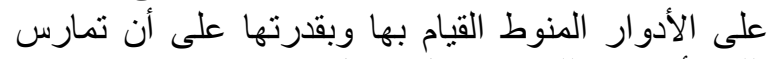

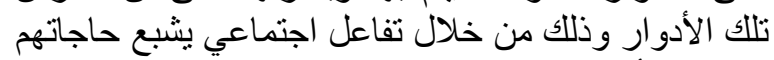
في إطار أهداف المجتمع التي تنضم إليه، وفي ضاعل التهاء القيم الآجتماعية السائدة.

لذا فان البحث الحالي قدة الطنلق من معطيات نظرية

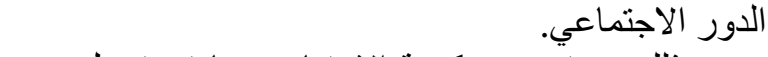
وذللك مع نوضيح كيفية الاستفادة منها في تفعيل دور التأمينات الاجتماعية.

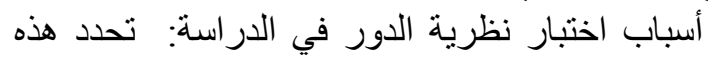

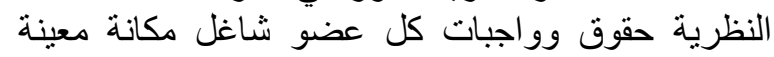
داخل التأمينات الاجتماعية وكعضو ولجئ داخل الخل جماعة.

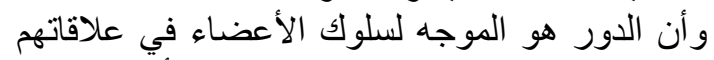

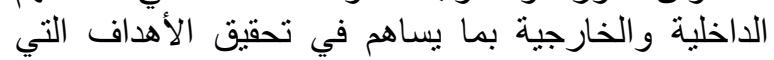

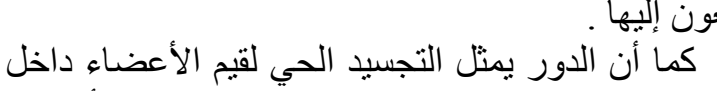

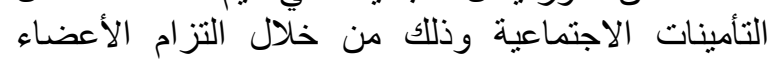
بالأدوار المسئولة عنها في إطار القئة القيم السائدة داخل الأل

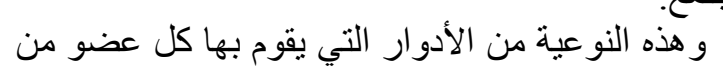

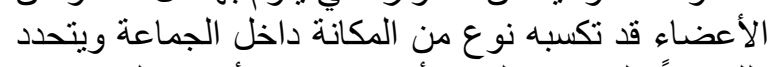

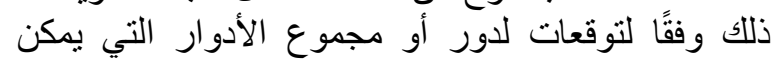




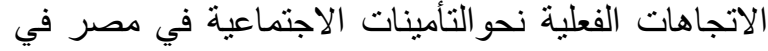

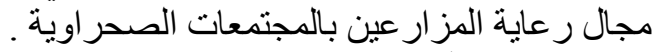
مجالات الار اسة : مالئز المجال البشري: أجريت تللك الدراسة بمحافظة الوادى

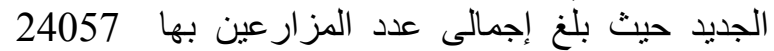
مزارع أعتبرت شاملة البحث ولاختئيار العينة تم تطبيق العبن

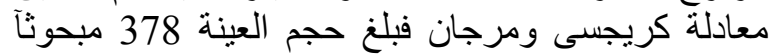

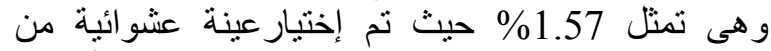
المشتركين و المستفيدين و وغير المشتركين بنظام التأمينات الاجتماعية ونوزع كالاتى: 126 مبحوثآ تحت سن

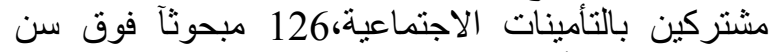

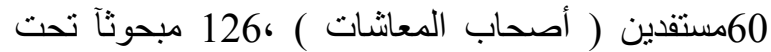
سن 60 غير مشتركين بالتأمينات الاجتماعية نم اختيار هم

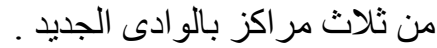
المجال الجغرافى : محافظة الوادى الجديد ( الخارجة ـ

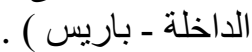

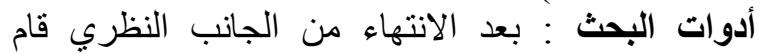

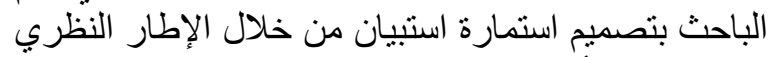

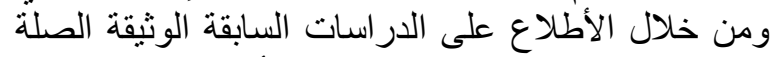

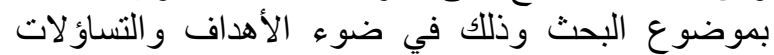
الخاصة بالبحث وقد استهدف الباحث من خلال استمارة

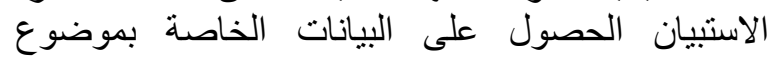
البحث:

\section{واشتملت الاستبانة على ما يلى :}

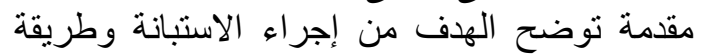

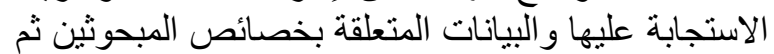

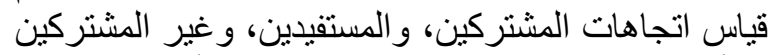

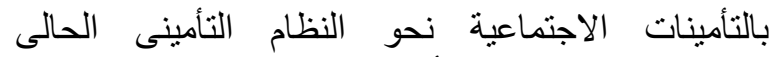
و الخدمات التي توفر ها التأمينات الاجتماتئاعية.

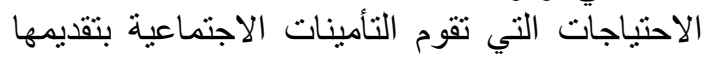

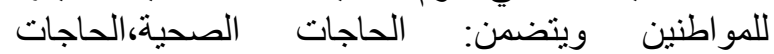

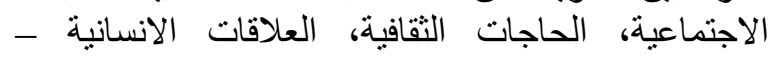

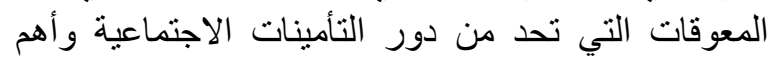
المقترحات التي تساعد على الحد من هذه المعوقات.

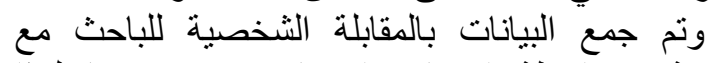
المبحوثين بواسطة استمارة أستبيان تم تصميمها لهذأل الغرض خلال شهر يوليو وسبتمبر الئمارة 2019 ـ المعالجة الكمية للبيانات

بعد الانتهاء من جمع البيانات البيانات على النحو السابق تم

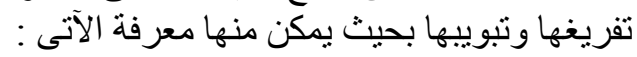

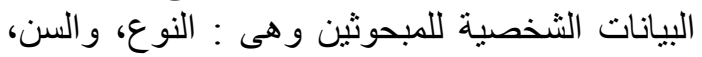

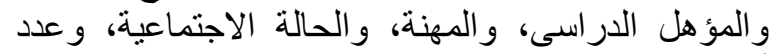

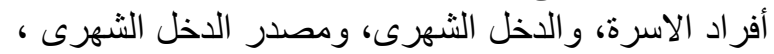

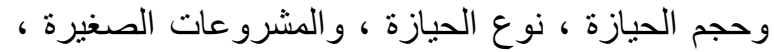

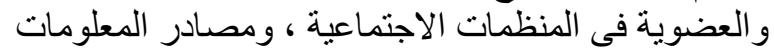
عن التأمينات الاجتماعية ، و الانشطة المفيدة الاعية التى يقدمها

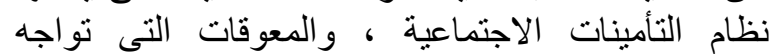
التأمينات الاجتماعية ومقترحاتهم لزيادة الأمعات دور التأمينات

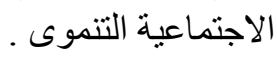

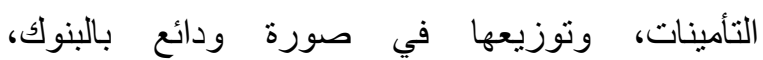

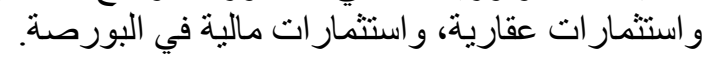

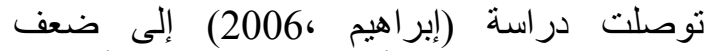

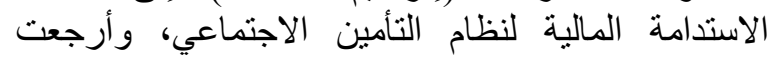

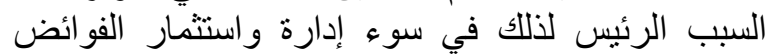

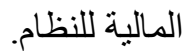

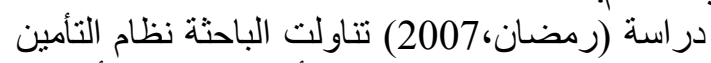

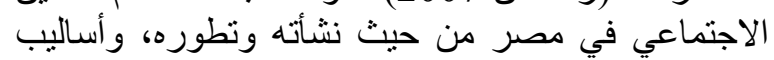

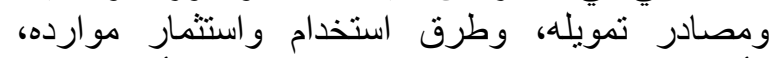

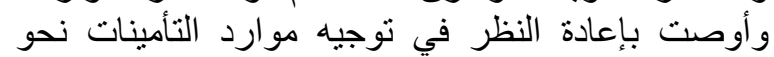

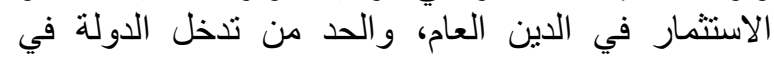
النظام، وتصفية مديونية الدولة للنظام من خلام خلال تمليكة

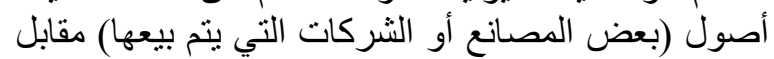

توصلت دراسة (المصرى ، 1983)إلى ضعف الإنى الأثر التوزيعى للتأمينات و الثنئون الإجتماعية فى مصر خلى خلال

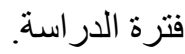

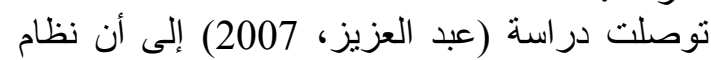

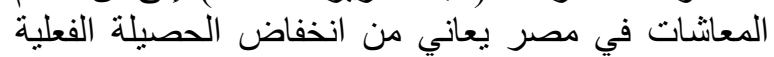

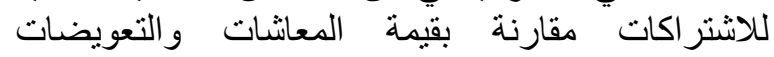

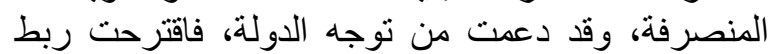

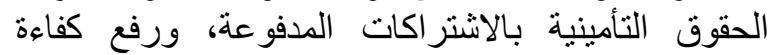
استثمار أموال التأمينات من خلالثرات صناديق الاستثمار الخاصة.

2 الإجراءات المنهجية للاراسة

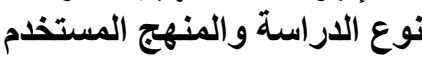
الدراسة وصفية، وتهدف إلى اللى التعرف على التى الواقع الفعلي ونقل صورة حقيقية عن الظاهرة المستهدفة الفية

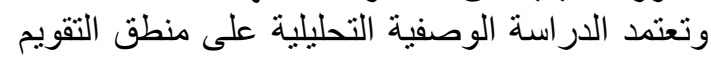

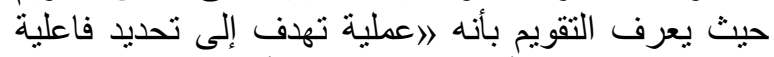

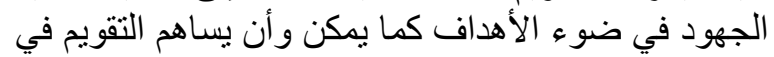
عملية تحسين التخطيط وتنفيذ البرامجياء.

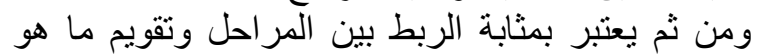

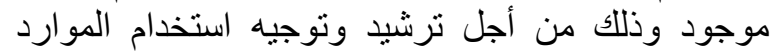
المتاحة والإماكنيات الموجودة سواء كاء كانت هذه الإند الإككانيات

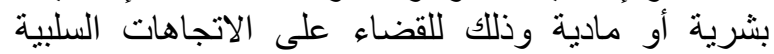
وتنمية الاتجاه الايجابى نحو التأمينات الاجنماعية. (Unesco,1984) و لا شك أن أي دراسة إذا اتخذت ضو ابط أو قواعد إند

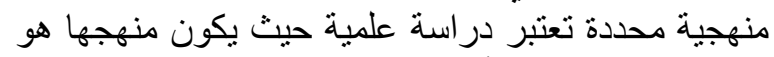

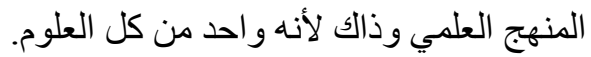

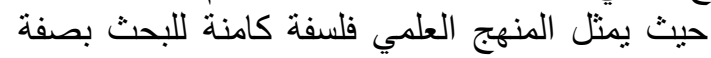

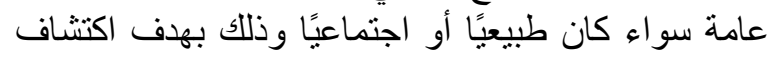

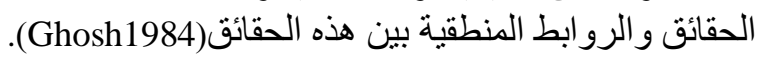

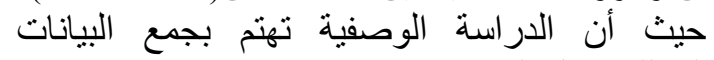
وتحليلها للوصول إلى نتائج يمكن تعميمها.

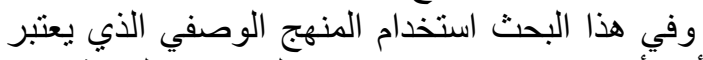

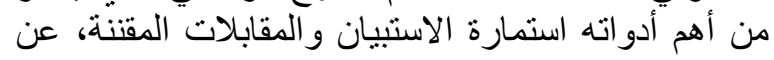

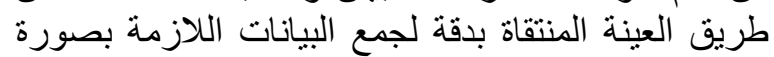
كافية ودقيقة وتفسير ها وتحليلها و استخلاص الينات النتائج لقياس 
2.3 - 2.3 السن

كما تثنير النتائج أن ما يزيد على غالبية المبحوثين

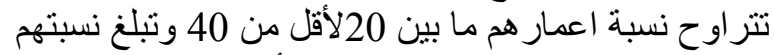

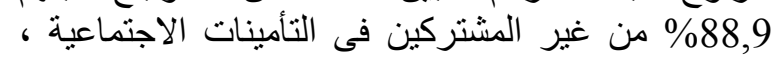
يليها المبحوثين المشتركين فى التنأمينات الاجتماعية التياعية

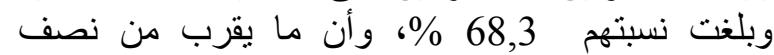
المبحوثين المستفيدين من التأمينات الاجتماعينتئر اوح من نسبة اعمار هم ما بين 60لاقل من 65 وبلغت نسبتهم 46,8 \%

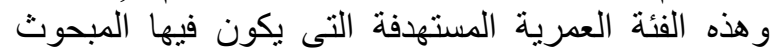

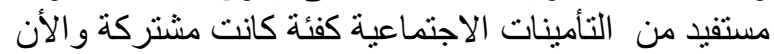

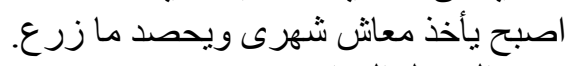

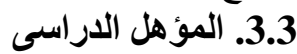
وتوضح النتائج ان ما يزيد على ثلثنى أفراد المبحوثين

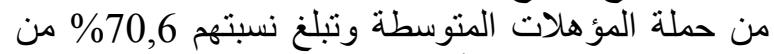

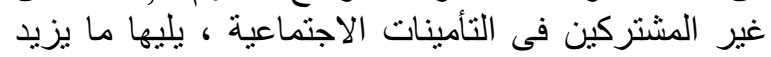

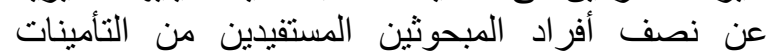

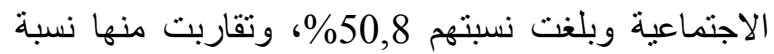

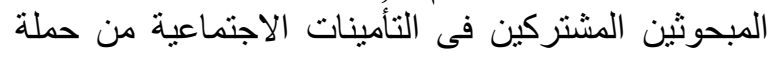

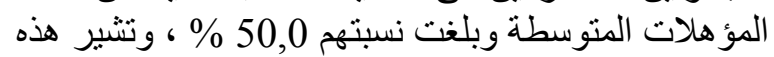

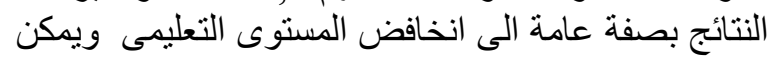

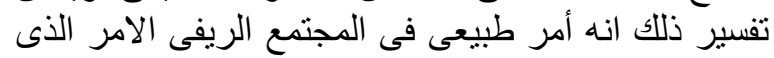

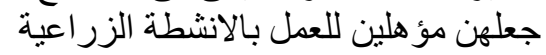

4.3

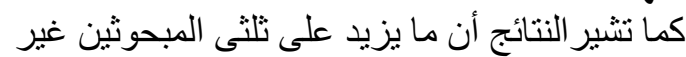

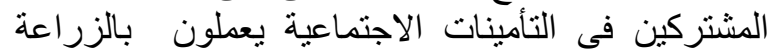

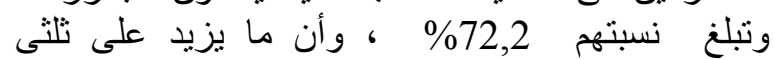
المبحوثين المشتركين فى التأمينات الاجتماعية يعملون مانى

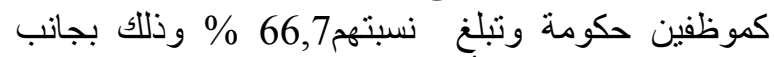

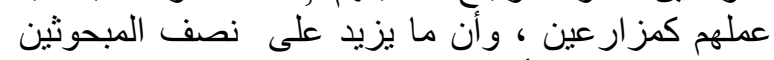

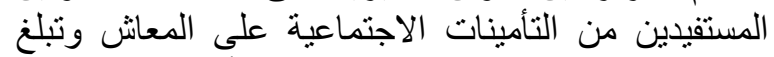

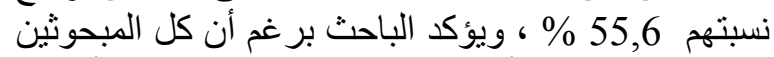

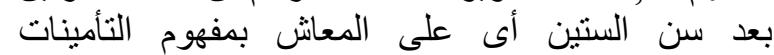

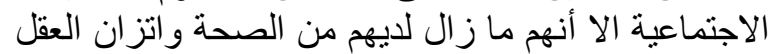

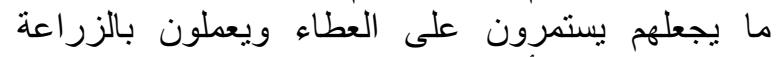
وبعض الاعمال الأخرى. 5.3.

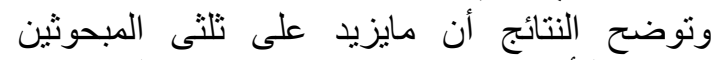

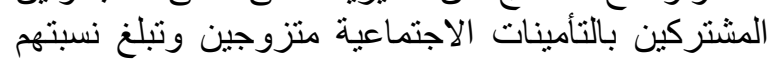

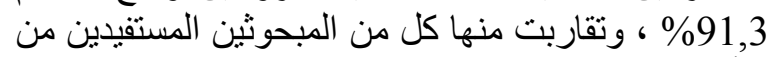

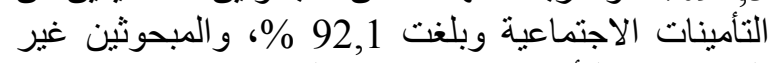

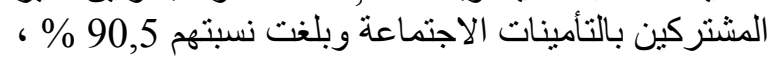

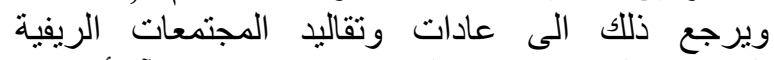
المصرية التى تحرص على زولى زاج الابناء مبكر آلأنه عفة الرئة

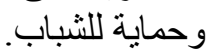

6. 6. قدأية أفراد الأسرة وتبين من النتائج تساوى نسبة المبحوثين المشتركين

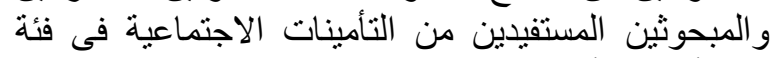

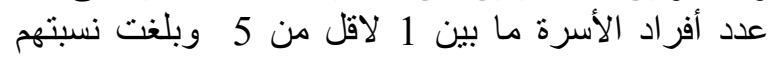

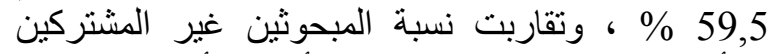
بالتأمينات الاجتماعية فى فئة عدد أفراد الأسرة ما بين 1 بن
البيانات الخاصة بالاتجاه نحو التأمينات الاجتماعية

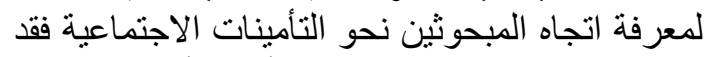
تضمن استمارة استبيان 16 عبارة لأخذ رأى الع المبحوثين

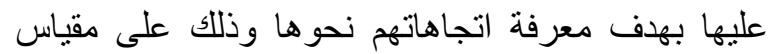

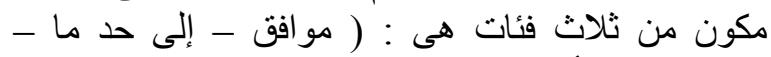

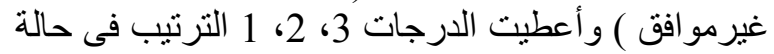

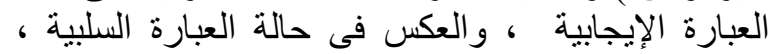

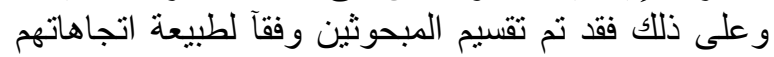

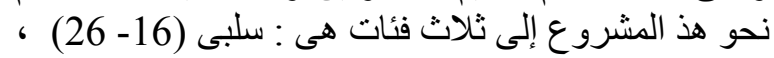

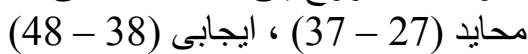
أدوات التحليل الاحصائى اليجى

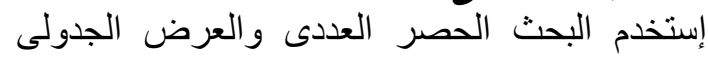
بالتكر ار و النسب المئوية لعرض البيان البيانات الثخصية لعينة

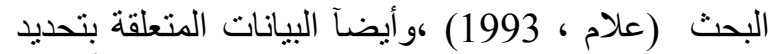

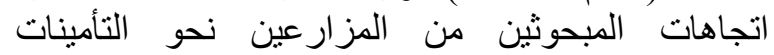

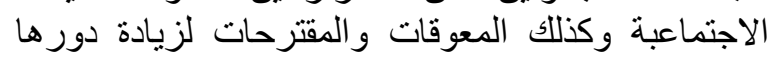

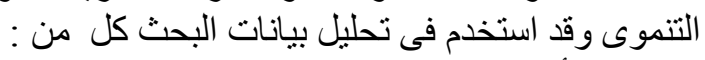

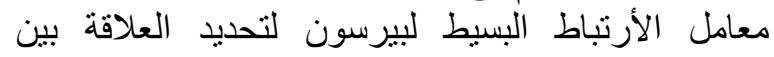

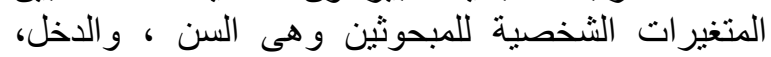

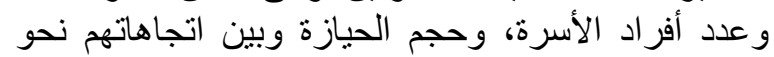
التأمينات الاجنماعية.

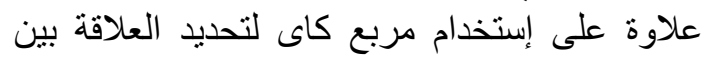

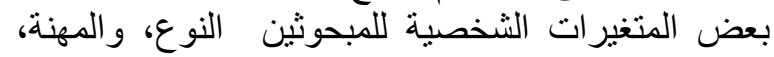

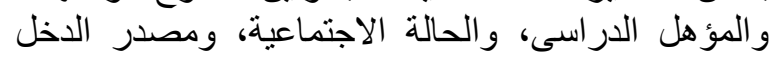

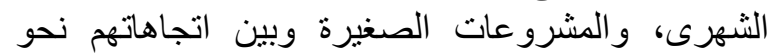

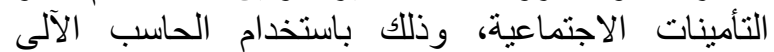

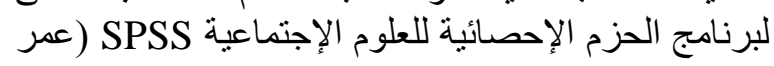

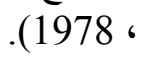

\section{3.النتائج ومناقشتها}

وصف عينة البحث لئن

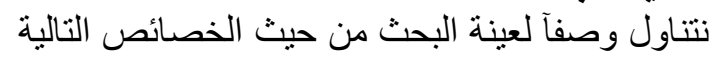

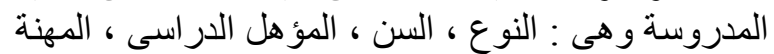

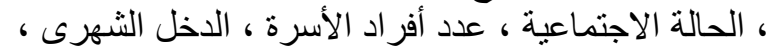

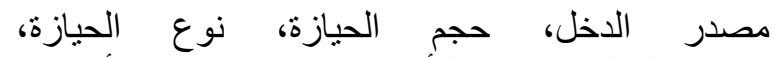

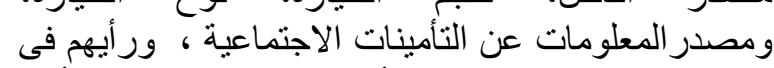

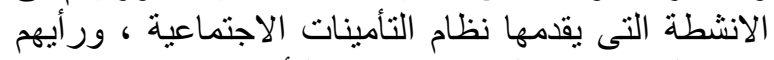

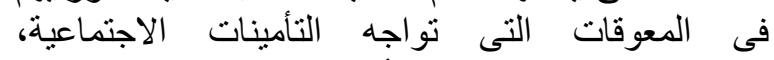

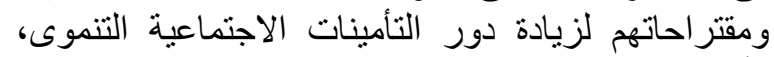

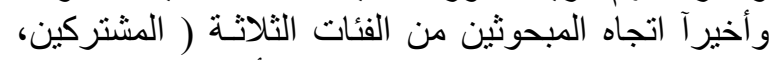
و المستفيدين ، و غبر المشتركين) نحو التأمينات الاجتماعية.

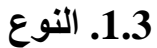
أوضحت النتائج (جدول1) أن ما يزيد على ثلثى فئى

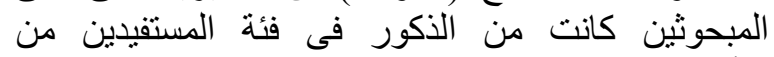

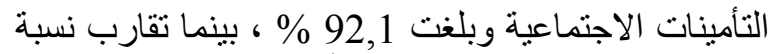

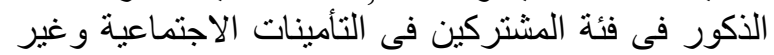

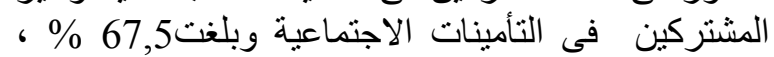

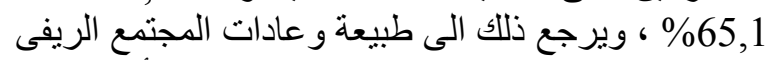

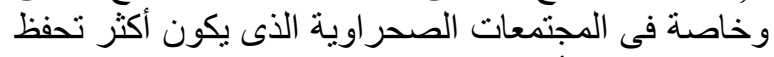

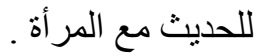




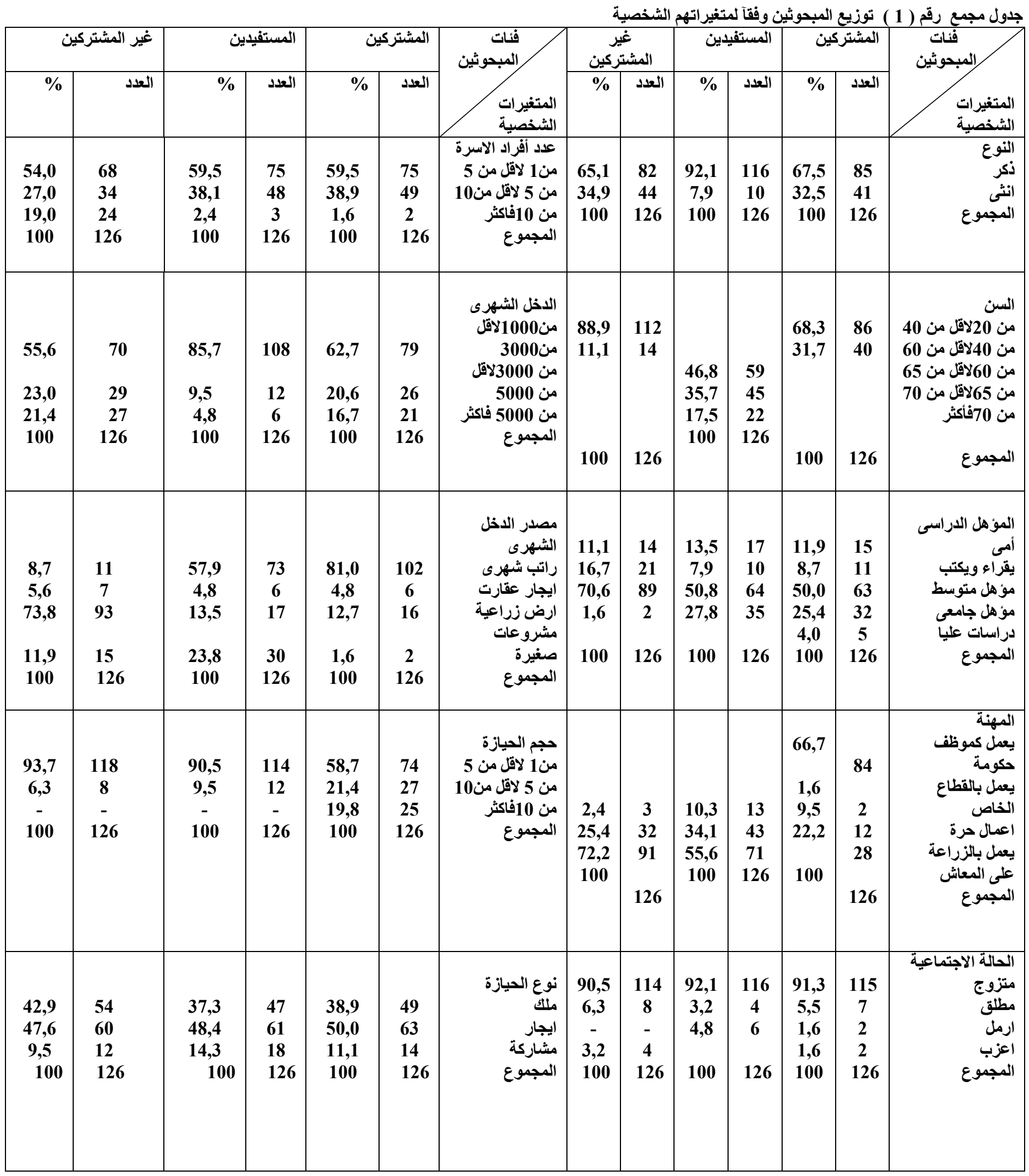

لاقل من 5 وبلغت54,0 \% \% ، وهو مؤشر جيد لتنطيم 7.3. الاخل الشهرى

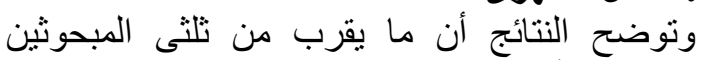

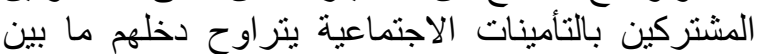

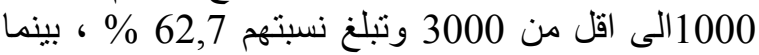

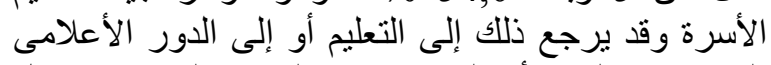

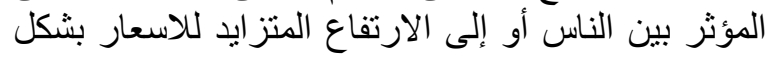

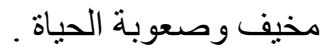


بالترتيب من خلال العمل وتبلغ نسبتهم 68,3 \% و ويرجع

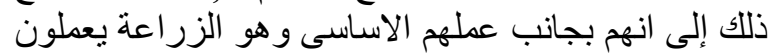

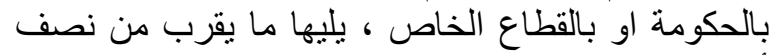
أفراد العينة يكتسبون المعلومة من الجيرة الجيران وكبار السن

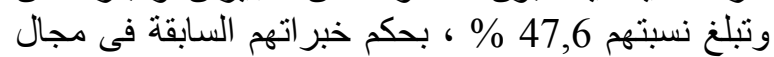

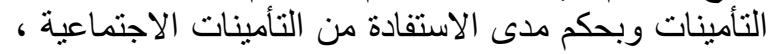

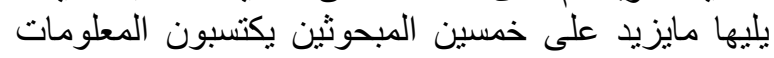

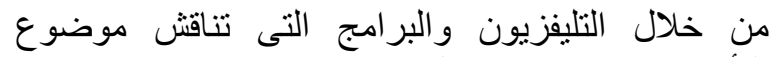

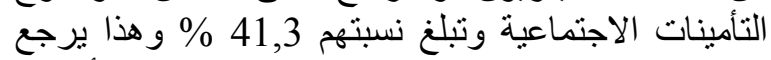

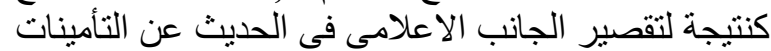

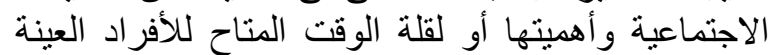

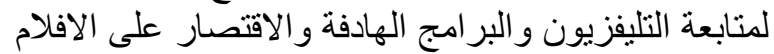

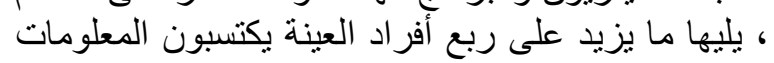

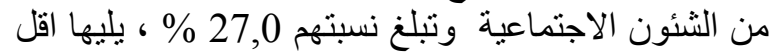

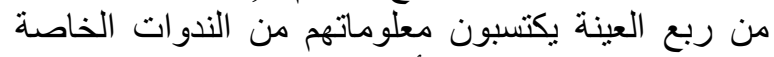
بالتو عية عن الاشتتر الك بالتأمينات الاجتماعية وتبلغ نسبتهم

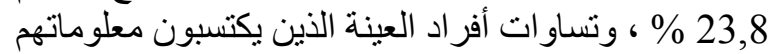

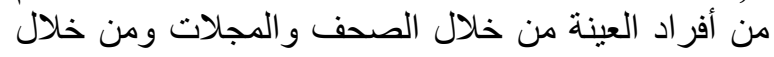

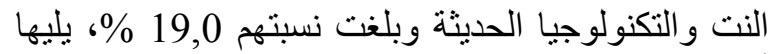

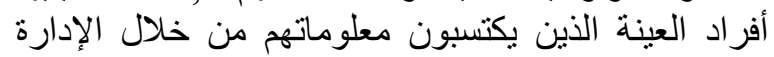

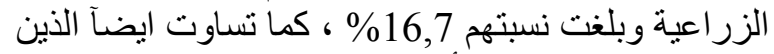

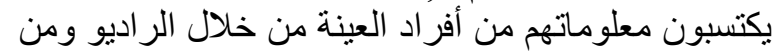

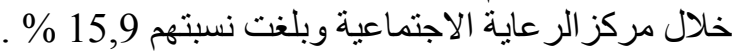
12. 3 التأمينات الاجتماعية المبنين

أوضحت النتائج (جدول 3) بالندبة الندة رأي المبحوثين

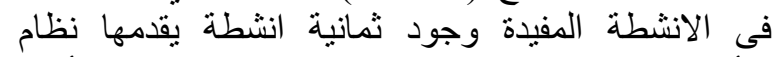
التأمينات الاجتماعية ، جاءت الاتئة بالترتيب انشاء شبكة أمان

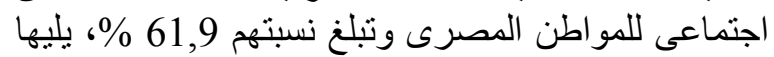

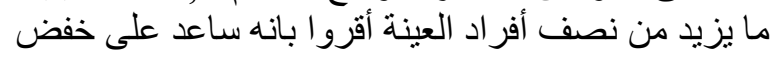

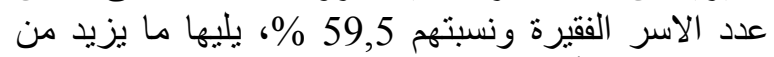

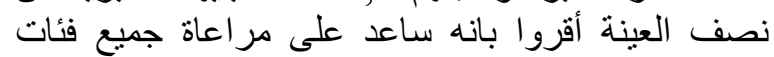

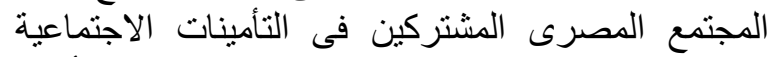

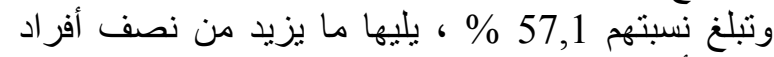

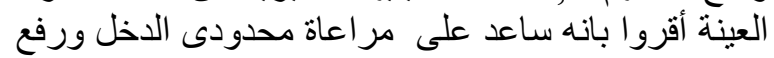

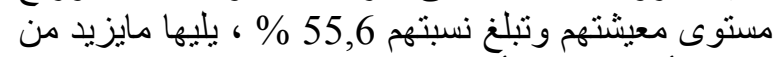

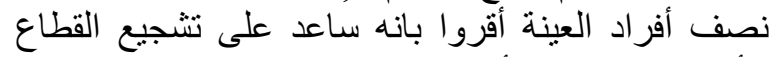

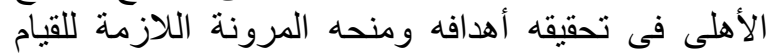

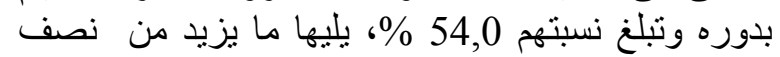

بلغت نسبة المبحوثين المستفيدين من التأمينات الاجتماعية

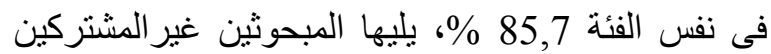

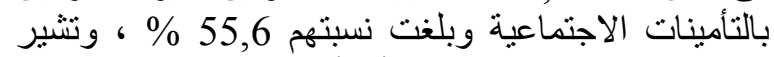

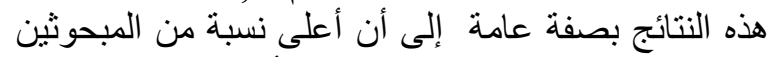

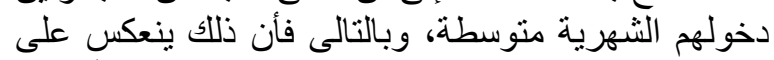
مستويات معيثتهم، وتلبية احتياجاتهم واحتياجات أسرهم المعيشية .

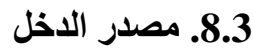

كما تشير النتائج أن ما يزيد على ثلثى ثلثى المبحوثين

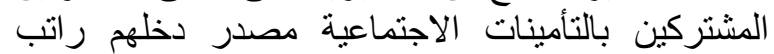

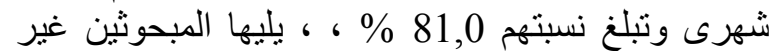

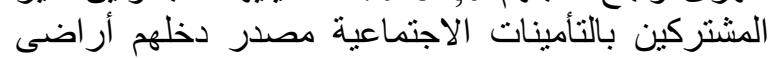

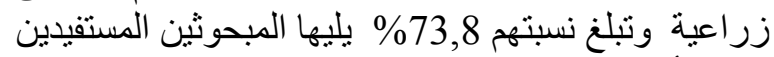

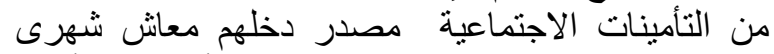

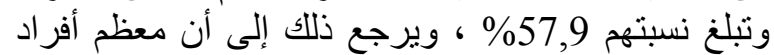

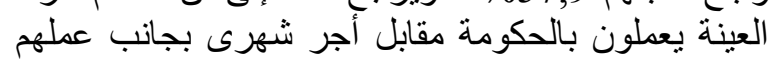

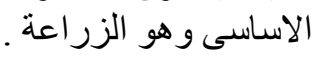

3 ـ 9 ـ حجم الحيازة الزئ

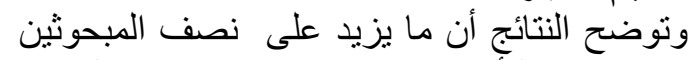

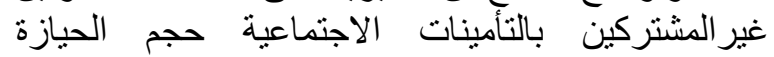

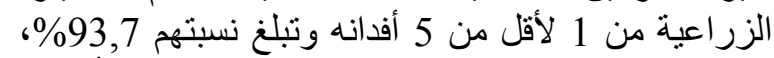

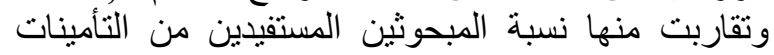

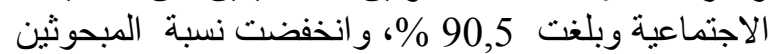

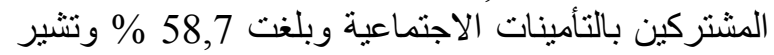

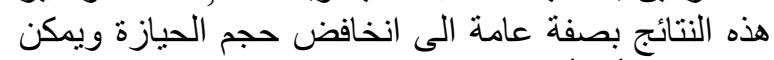

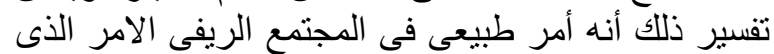

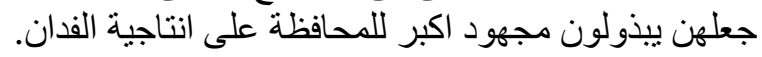

30 ـ 10 ـ نوع الحيازة وتبين النتائج ان نصف نصف المبحوثين المشتركين

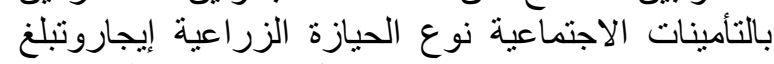
نسبته\%50,0\% ، وتقاربت منها كل من نسبة الزبة المبحوثين

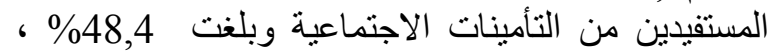
ونسبة المبحوثين غير المشتركين بالتأمينات الاجتماعية

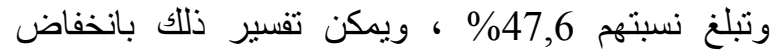

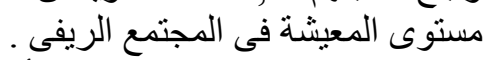
3 ـ 11. مصادر المطلومات عن التأمينات الاجتماعية الإية

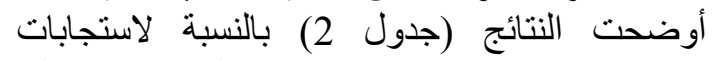

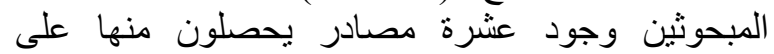

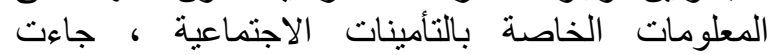

\begin{tabular}{|c|c|c|c|c|}
\hline الرتبة & $\%$ & 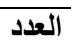 & مصادر المعلوماتكا & b \\
\hline 1 & 68,3 & 86 & من العمل & 1 \\
\hline 3 & 41,3 & 52 & من التلبفزيون (البر امج تناقش موضوع التأمينات الا جتماعية ) & 2 \\
\hline 9 & 15,9 & 20 & من خلال الر اديو & 3 \\
\hline 8 & 16,7 & 21 & الادارة الزر اعية & 4 \\
\hline 4 & 27,0 & 34 & الثشئون الاجتماعية & 5 \\
\hline 2 & 47,6 & 60 & من الجيران وكبار السن & 6 \\
\hline 10 & 15,9 & 20 & من خلال مركز الر عاية الاجنماعية & 7 \\
\hline 6 & 19,0 & 24 & من خلال الصحف و المجلات & 8 \\
\hline 5 & 23,8 & 30 & الندوات الخاصة بالتو عية عن الاشتر اك بالتأمينات الاجتماعية & 9 \\
\hline 7 & 19,0 & 24 & من خلال النت و التكنولوجيا الحديثة & 10 \\
\hline
\end{tabular}


جدول (3): توزيع المبحوثين وفقآ لرأيهم فى الانشطة التى يقامها نظام التأمينات الاجتماعية.

\begin{tabular}{|c|c|c|c|c|}
\hline الرتبة & $\%$ & 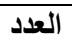 & الحاجات المفيدة اللى عملها نظام التأمينات الاجتماعية & $p$ \\
\hline 1 & 61,9 & 78 & انشاء شبكة أمان اجتماعى للمو اطن المصرى & 1 \\
\hline 2 & 59,5 & 75 & خفض عدد الأسر الفقيرة & 2 \\
\hline 7 & 50,8 & 64 & زيادة نسبة اشباع متطلبات المواطنيين المشتركين و أسر هم & 3 \\
\hline 4 & 55,6 & 70 & مر اعاة محدودى الدخل ورفع مستوى معيشتهم & 4 \\
\hline 8 & 50,0 & 63 & تحسين الخدمات التأمينية التى تقدم للمو اطنيين المشتركين و أسر هم من بعدهم & 5 \\
\hline 3 & 57,1 & 72 & مر اعاة جميع فئات المجتمع المصرى المشتركين فى التأمينات الاجتماعية & 6 \\
\hline 6 & 53,2 & 67 & مر اعاة البعد الاجتماعى عند وضع البر امج المختلفة للخدمة و الإهتمام به & 7 \\
\hline 5 & 54,0 & 68 & تشجيع القطاع الأهلى فى تحقيقه أهدافه ومنحه المرونة اللازمة للقيام بدوره & 8 \\
\hline
\end{tabular}

كل المو اطنيين وتبلغ نسبتهم 75,3 \% ، يليها ما يزيد

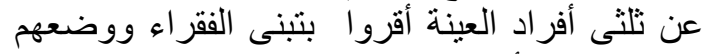

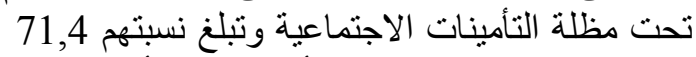
\% ، يليها ما بزيد من نلثى أفراد العينة أقروا تفعيل

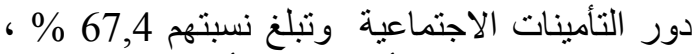

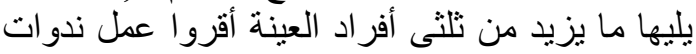

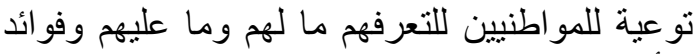

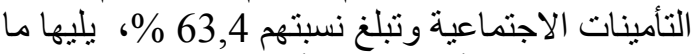

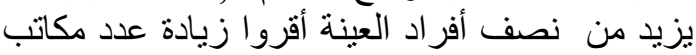

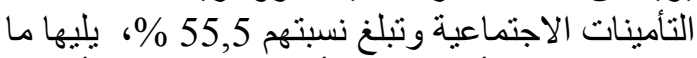
يقل عن نصف أفراد العينة أقروا ان تشمل التمل التأمينات

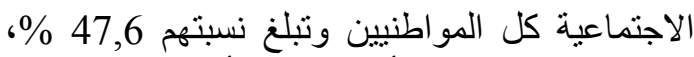
اليليها ما يقل عن ثلث ألثراد العند العينة أقروا بزيادة قيمة

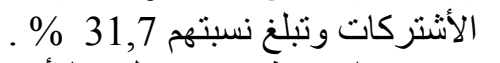

15.اتجاه المبحوثين نحو نظام التأمينات الاجتماعية

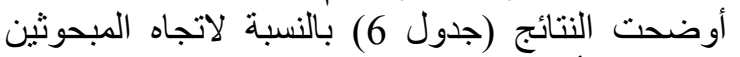

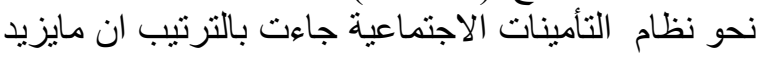

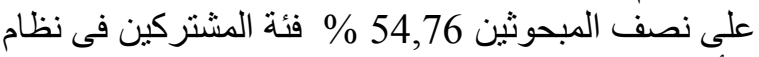

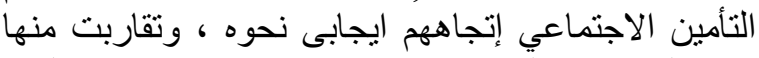

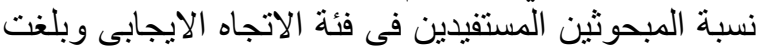

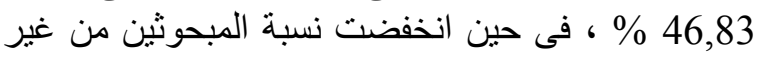

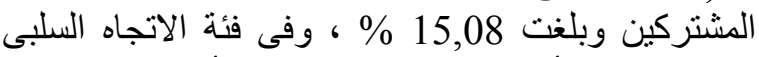

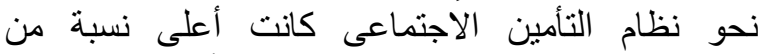
المبحوثين غير المشتركين فى نظام الاجني التأمين الاجتماعي

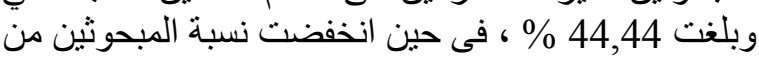

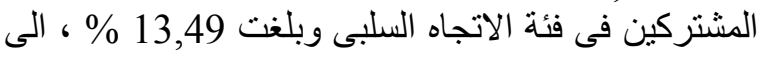

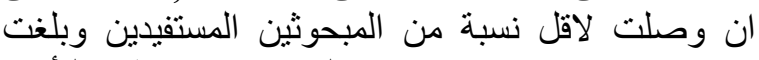

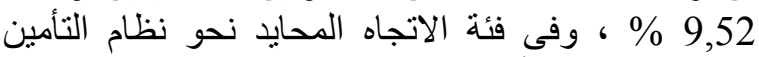

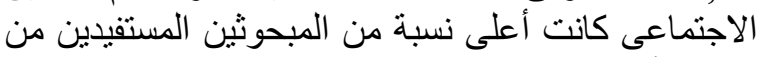

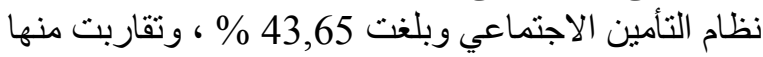
نسبة المبحوثين من غير المثنتركين في فئة الاتجاه المحايد

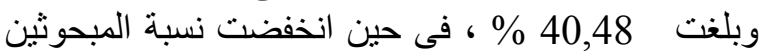

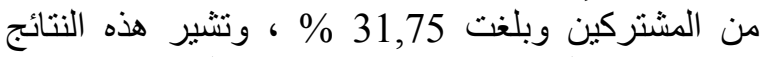

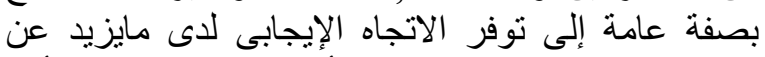

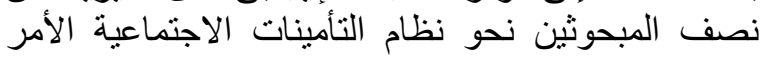

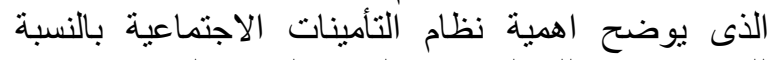

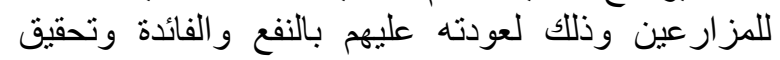

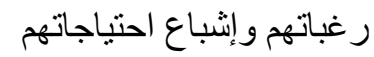

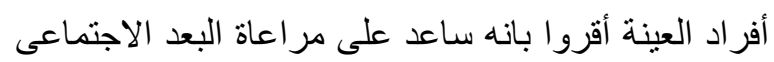

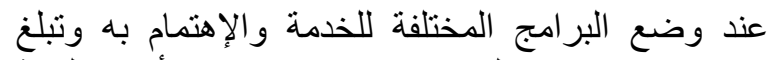

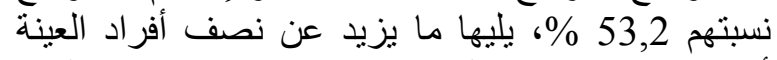

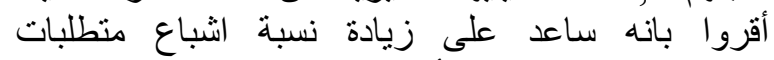

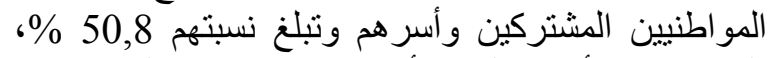

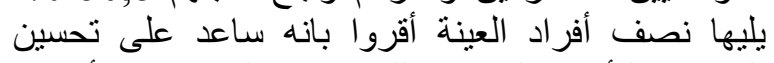

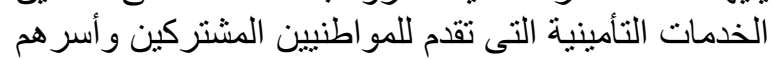

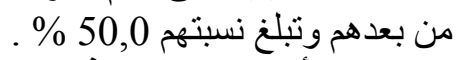

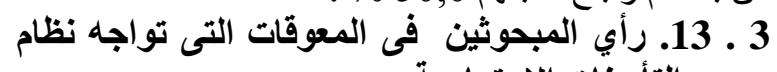
التأمينات الاجتماعية البحنية

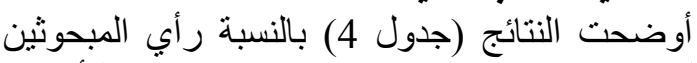

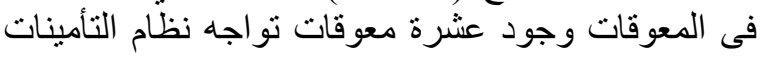

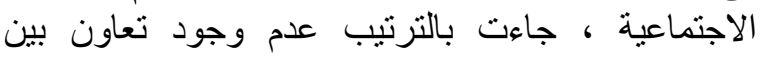

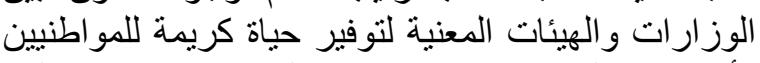

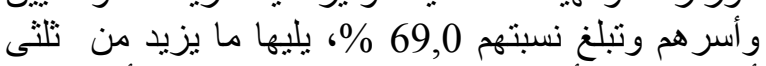

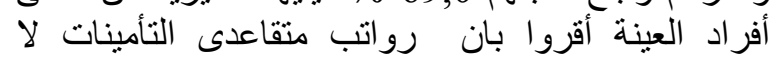

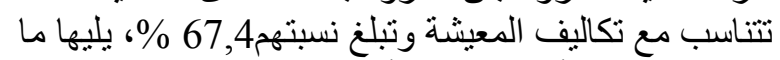

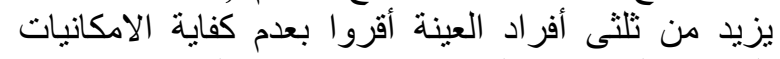

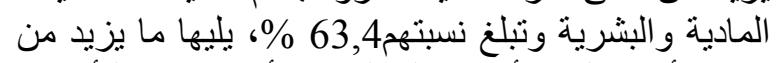
نصف أفر اد العينة أقروا بقلة الوبنة الوعى بأهمية دور التأمينات

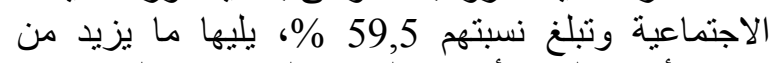

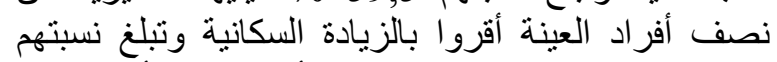

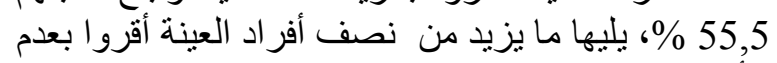

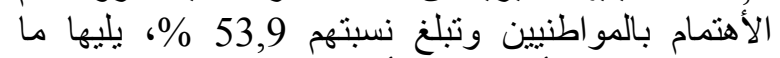

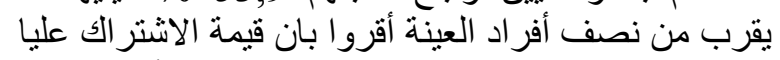

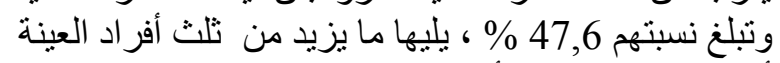

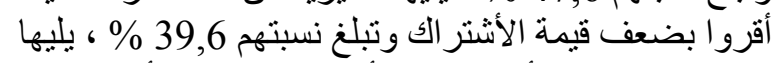

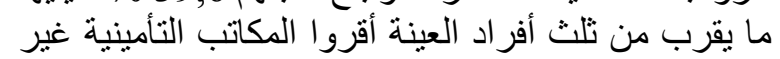

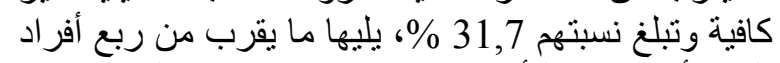

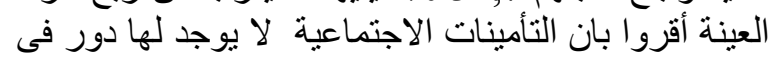

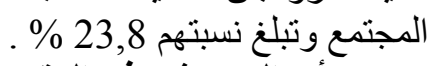
14.3.رأي المبحوثين في المقترحات لزيادة دور التأمينات

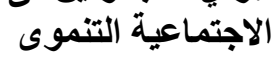

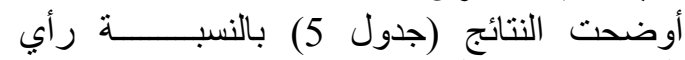

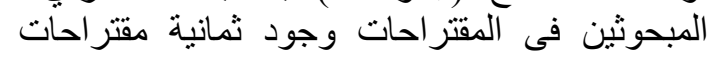

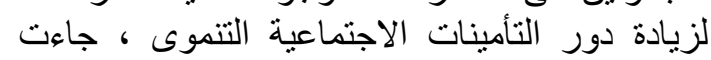

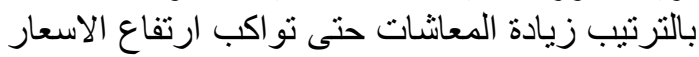

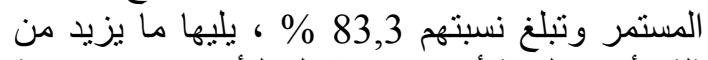
ثلثى أفر اد العينة أقروا بان تتمل التأمينات الاجتماعية 
جدول (4): توزيع المبحوثين وفقآ لر أيهر فى المعوقات التى تواجه التأمينات الاجتماعية.

\begin{tabular}{|c|c|c|c|c|}
\hline الرتبة & $\%$ & العدد & 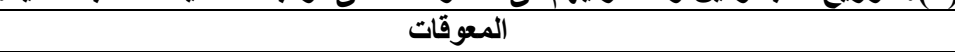 & b \\
\hline 5 & 55,5 & 70 & الزيادة السكانية & 1 \\
\hline 4 & 59,5 & 75 & قلة الو عى بأهمية دور التأمينات الاجتماعية & 2 \\
\hline 2 & 67,4 & 85 & رواتب متفاعدى التأمينات لا تتتاسب مع تكاليف المعيشة & 3 \\
\hline 3 & 63,4 & 80 & عدم كفاية الامكانيات المادية و البشرية & 4 \\
\hline 8 & 39,6 & 50 & ضتف قيمة الاشتر اك & 5 \\
\hline 6 & 53,9 & 68 & عدم الاهتمام بالمو اطنيين & 6 \\
\hline 9 & 31,7 & 40 & المكاتب التأمينية غير كافية & 7 \\
\hline 10 & 23,8 & 30 & لا يوجد لها دور فى المجتمع & 8 \\
\hline 7 & 47,6 & 60 & قيمة الانشتر الك عليا & 9 \\
\hline 1 & 69,0 & 87 & عدم وجود تعاون بين الوزار ات و الهيئات المعنية لتوفير حياة كريمة للمو اطنيين و أسر هم & 10 \\
\hline
\end{tabular}

جدول (5): توزيع المبحوثين وفقآ للمقترحات لزيادة دور التأمينات الاجتماعية التنموى.

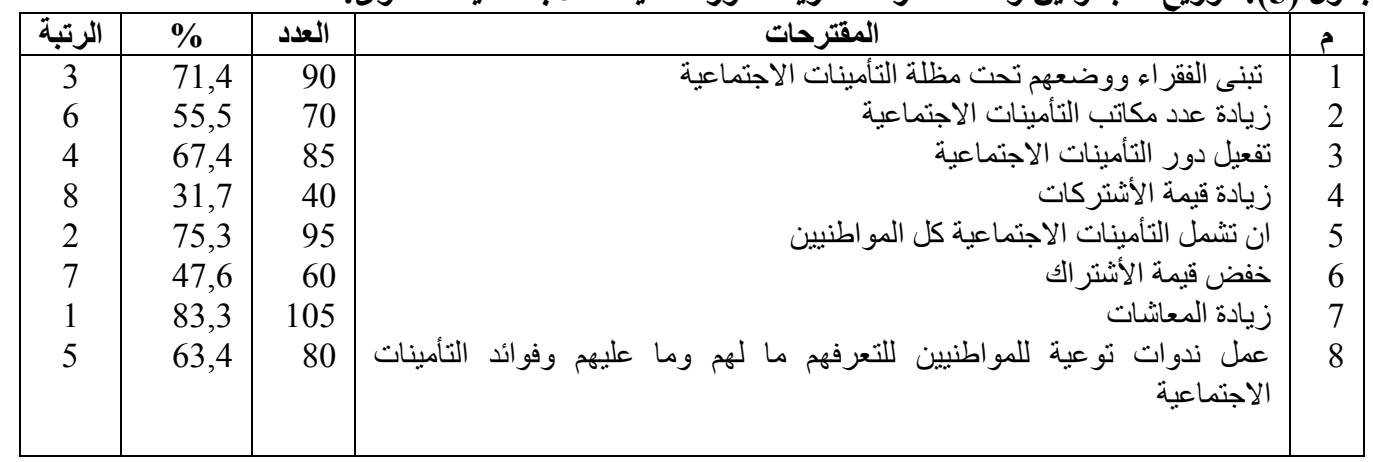

جدول رقم (6): إتجاه المبحوثين من الفئات الثثلاثة نحو التأمينات الاجتماعية.

\begin{tabular}{|c|c|c|c|c|c|c|}
\hline \multicolumn{2}{|c|}{ غير المشتركين } & \multicolumn{2}{|c|}{ المستفياين } & \multicolumn{2}{|c|}{ المشتركين } & 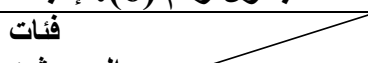 \\
\hline$\%$ & العدد & $\%$ & العدد & $\%$ & 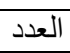 & طبيعة الاتجاه \\
\hline 44,44 & 56 & 9,52 & 12 & 13,49 & 17 & سلب (16 - 26) \\
\hline 40,48 & 51 & 43,65 & 55 & 31,75 & 40 & محايد ( 27 - 37 ) \\
\hline 15,08 & 19 & 46,83 & 59 & 54,76 & 69 & ايجابى ( 38 - 48 ) \\
\hline
\end{tabular}

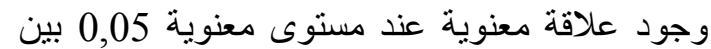

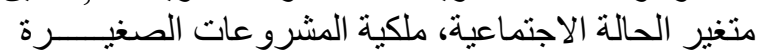

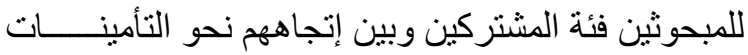

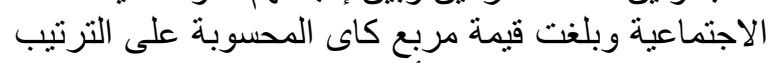

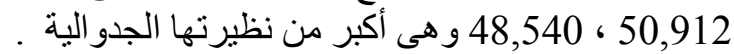
نتائج أختبار معامل الارتباط البسيط أتضح من النتائج فى (جلى (جدول

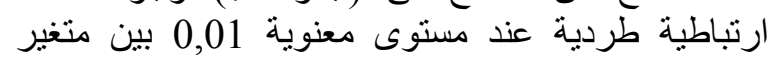

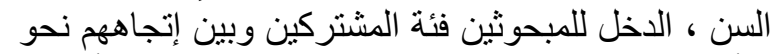

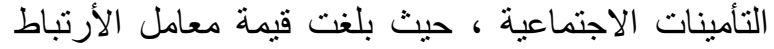

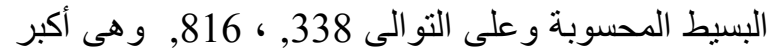

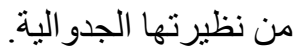
عدم وجود علاقة ارتباطية معنوية بين متغير عدازية

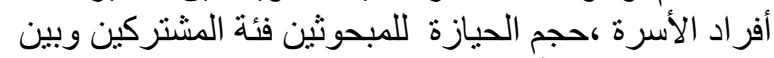

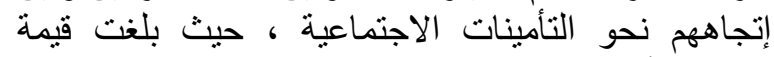

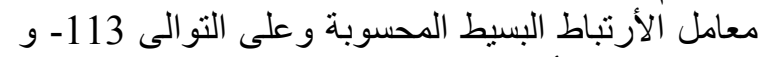
049 - و و هوثى أقل من نظيرنها الجدو الية .

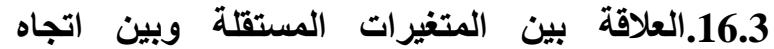
المبحوثين من فئة المشتركين في نظام التأمينات الاجتماعية

بنص الفرض الاحصائى الأول على أنه " لا توجد

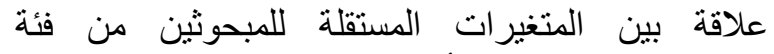

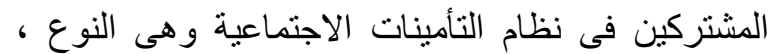

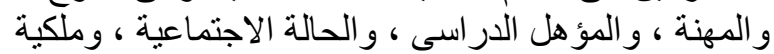

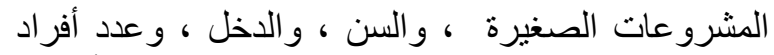

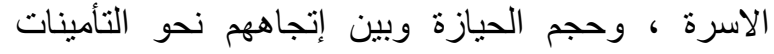

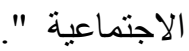

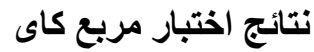
إتضح من النتائج فى (جدول

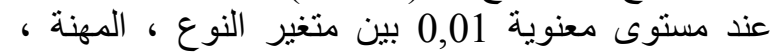

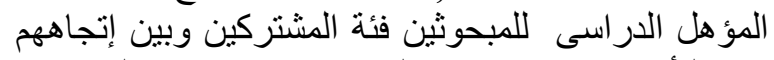

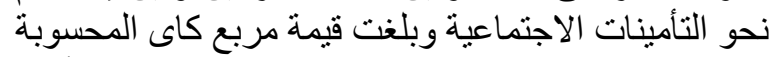

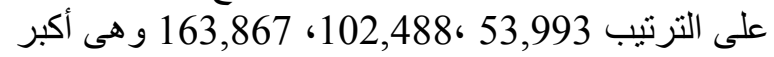

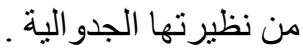




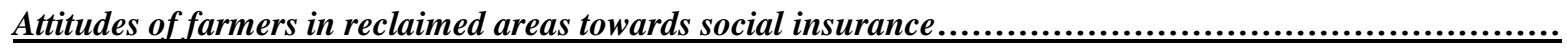

جدول رقم (7 ): العلاقة بين المتغيرات المستقلة وبين اتجاه المبحوثين من الفئات الثثلاثة نحو التأمينات الاجتماعية.

\begin{tabular}{|c|c|c|c|c|c|c|c|c|c|}
\hline \multicolumn{3}{|c|}{ غير المشتركين } & \multicolumn{3}{|r|}{ المستفيدين } & \multicolumn{3}{|r|}{ المشتركين } & \multirow{2}{*}{ لهئزات المبحوثين } \\
\hline قالارتباط معامل & المعنتوية & كا & الآرتباط معامل & المعنوية & كا & قالارتباط معامل & المنتوية & 215 & \\
\hline & 9000 & 64,641 & & 9037 & 23,375 & & 9000 & 53,993 & النوع \\
\hline & 9002 & 77,847 & & 9001 & 63,739 & & 9001 & 102,488 & المهنة \\
\hline & 9020 & 95,341 & & 9002 & 130,860 & & 9000 & 163,867 & المؤهل الدراسى \\
\hline & 9001 & 83,649 & & 9003 & 116,619 & & 9028 & 50,912 & الحالة الاجتماعية \\
\hline & 9000 & 65,792 & & 9001 & 42,940 & & 9015 & 48,540 & الصغية المشرو عات \\
\hline$*, 181$ & & & $* *, 220$ & & & $* *, 338$ & & & السن \\
\hline$*, 178$ & & & $*, 182$ & & & $* *, 816$ & & & الاخل \\
\hline$*, 184$ & & & $*, 194$ & & & و9113- & & & عدد أفراد الأسرة \\
\hline$*, 195$ & & & $*, 217$ & & & 9049- & & & حجم الحيازة \\
\hline
\end{tabular}

الحالة الاجتماعية باختلاف انو اعها لها تأثثر فى مدى اتجاه

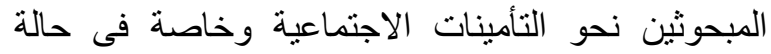

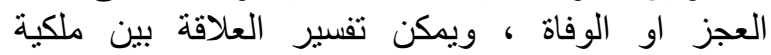

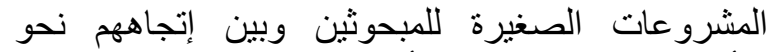

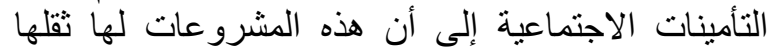

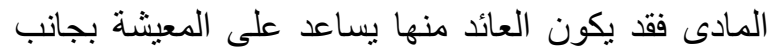

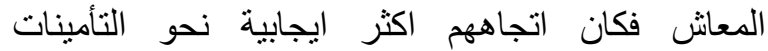

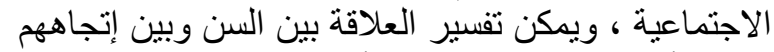

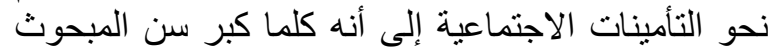

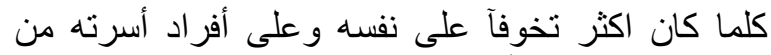

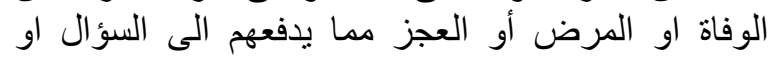

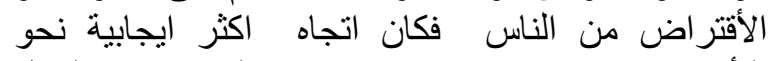

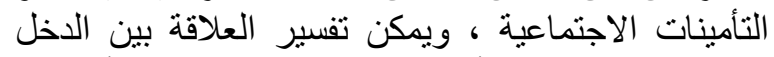

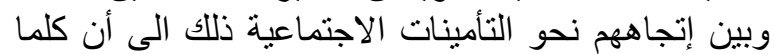

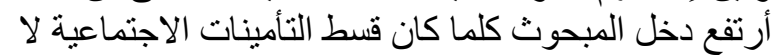
يمثل عبء عليه وعلى أسرته فيكون اتجاه اكثر ايجابية نحو التأمينات الاجتماعية .

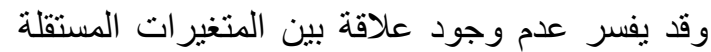

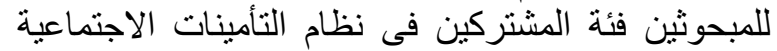

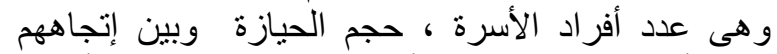

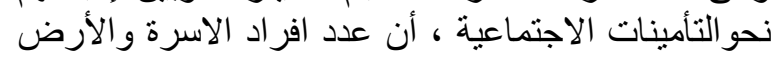

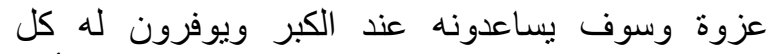

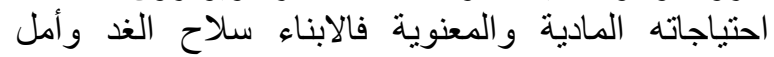

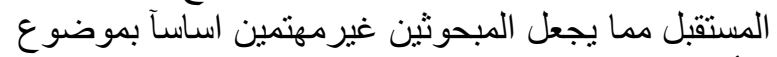
التأمينات الاجتماعية.

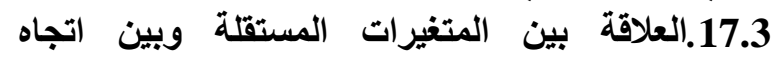
المبحوثين من فئة المستفيدين من نظام التأمينات الاجتماعية

ينص الفرض الاحصائى الأول على أنه " لا توجد

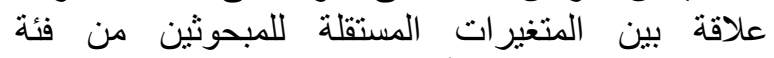

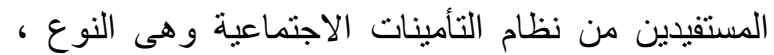

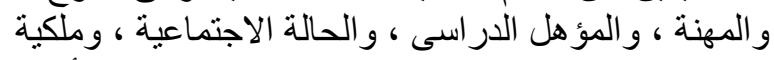
المشروعات الصغيرة ، و والسن ، و الدخل ، و وعدد أفراد الناعة

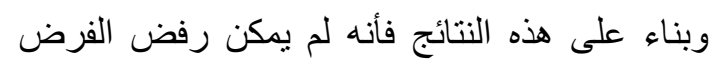

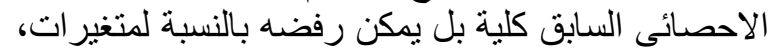

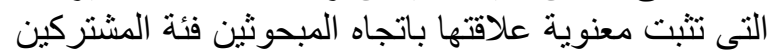

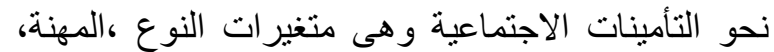

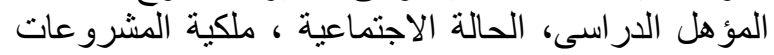

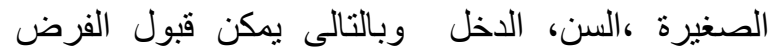

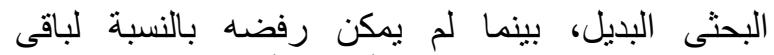

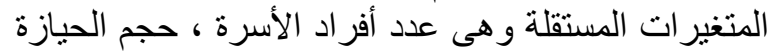

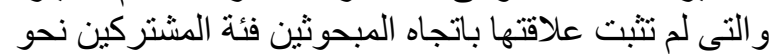
التأمينات الاجتماعية.

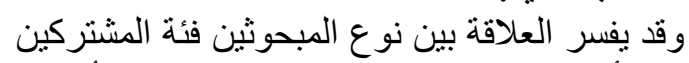

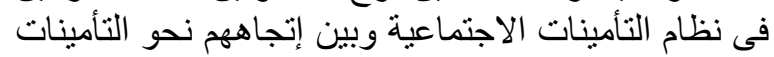

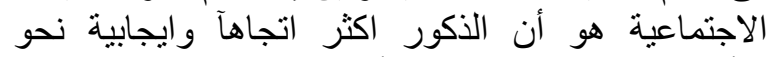

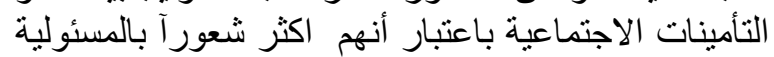

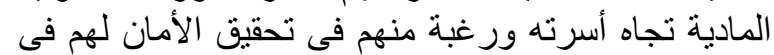

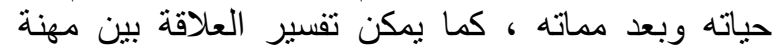

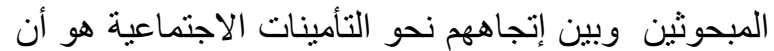

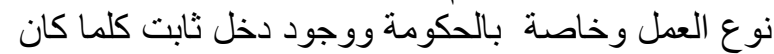
اتجاهه اكثرايجابية نحو التأمينات الاجتماعية وزية وزاد الاقية الاقبال على الأشتر الك فى التأمينات الاجتماعية حيث أن النيات التأمينات الاقيات

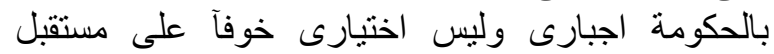
المواطنيين وحرص الحكومة على الحئ اسثمار أمو ال التأمينات

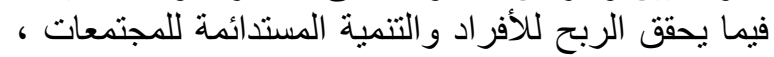

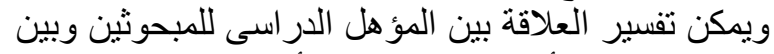

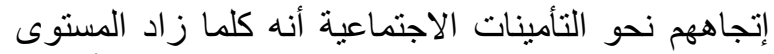

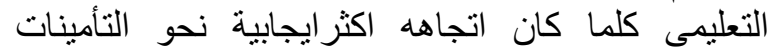

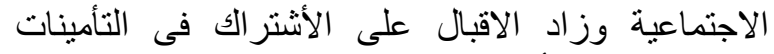

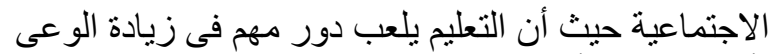

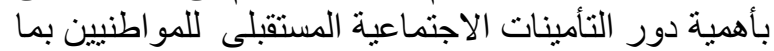

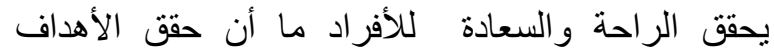

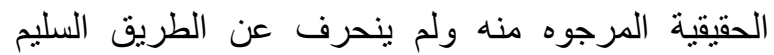

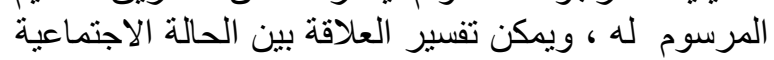
للمبحوثين وبين إتجاههم نحو التأمينات الاجتماعية أن النين 
غير المشتركين وبين إتجاههم نحو التأمينات الاجتماعية

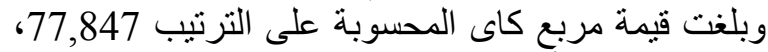

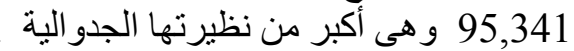

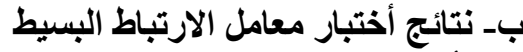

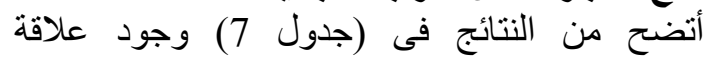
ارتباطية طردية عند مستوى معنوية

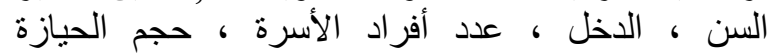

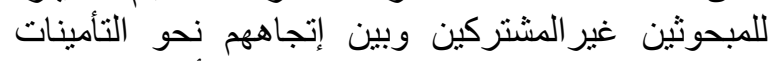

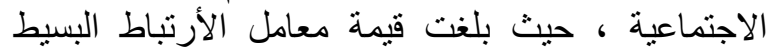

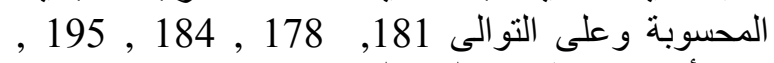
و هى أكبر من نظيرتها الجدو الية .

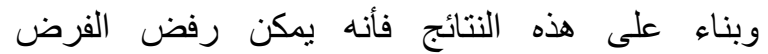
الاحصائى السابق كلية مع المبحوثين فئة غير المشنتركين

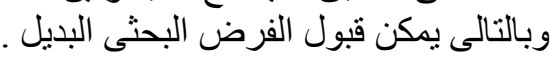
توصيات البحث

انشاء مركز للأبحاث و التطوير ، لدر اسة أهم الانشطة

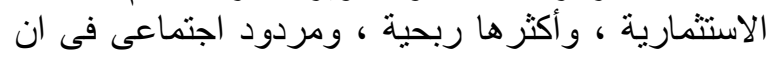

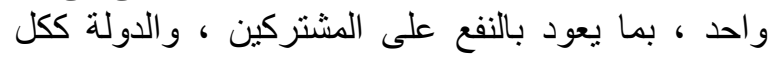

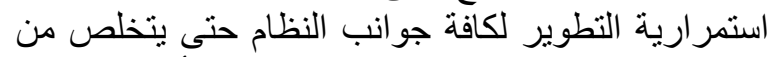

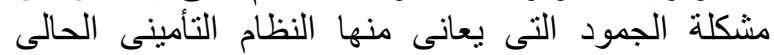

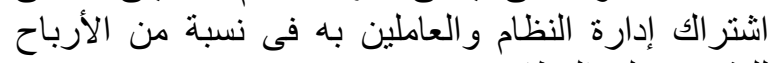
للتشجيع على العطاء.

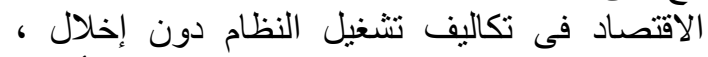
لتجنب امتصاص تكلفة تشغيل النظام لقدر كبير من الأرباح

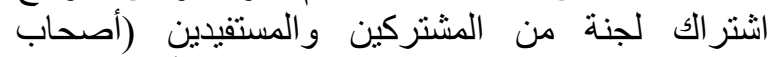

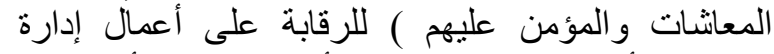

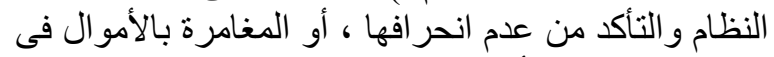

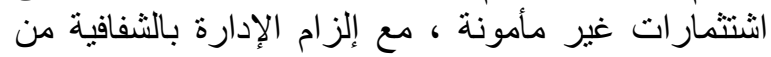

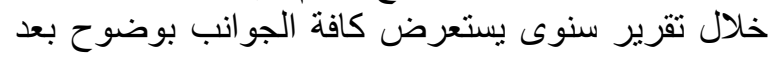

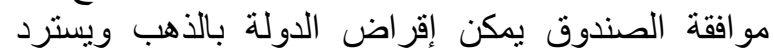

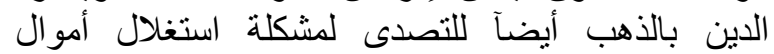

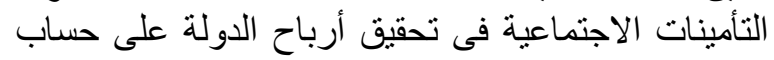

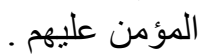

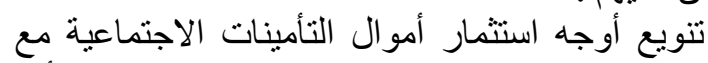

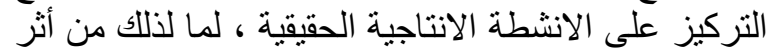

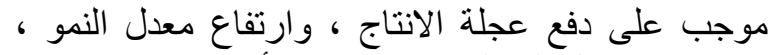

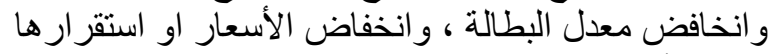

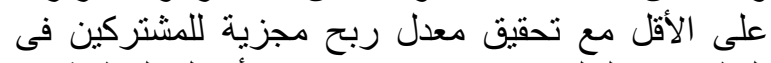

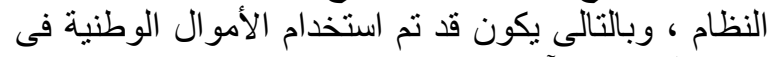

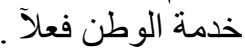
دراسة المشروعات بعناية فائقة قبل الإقدام عليها

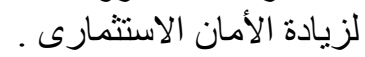
تنوع أوجه الاستثمار أمر ضرورى لتخفيض مخاطر

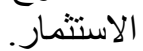
الاحتفاظ برصيد سيولة 25\% احتياطى نقدى لدى

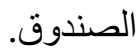

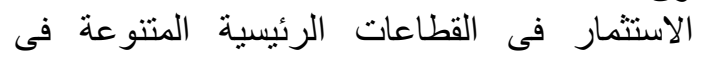

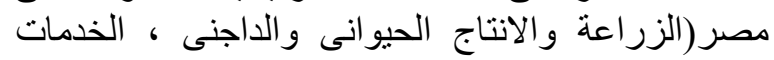
،الاتصالات وتكنولوجيا المعلومات ، الصناعة ولاجنى ، السياحة ) الخدات
الاسرة ، وحجم الحيازة وبين إتجاههم نحو التأمينات

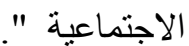
نتائج اختبار مربع كاى "أى

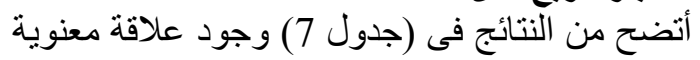

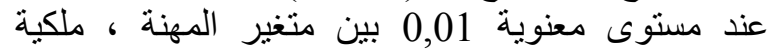

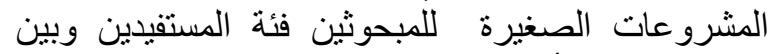

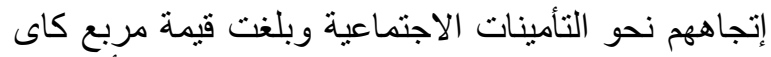

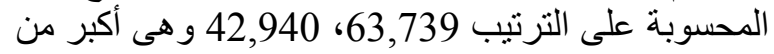

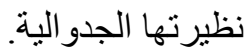

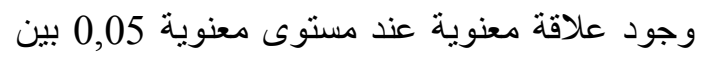

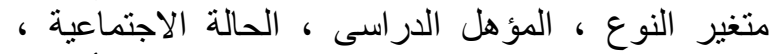

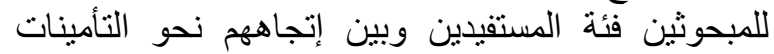
الاجتماعية وبلغت قيمة مربع كاى المحسوبة على الئ الترتيب

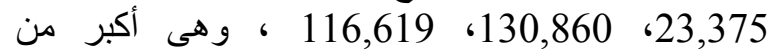
تظبرنها الجدو البة البه

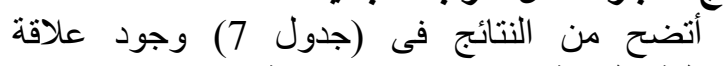

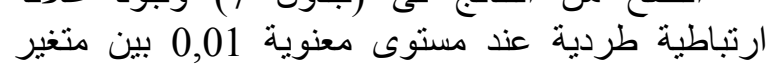

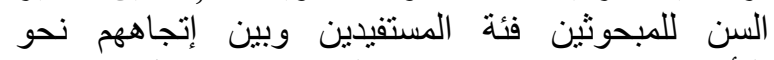
التأمينات الاجتماعية ، حيث بلغين البنت قيمة معامل الإرنباط

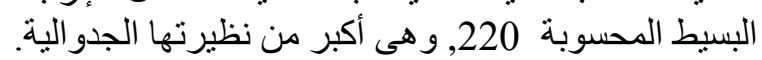

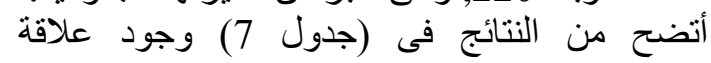
ارتباطية طردية عند مستوى معنوية

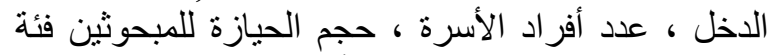

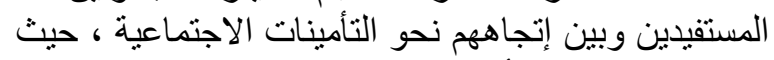

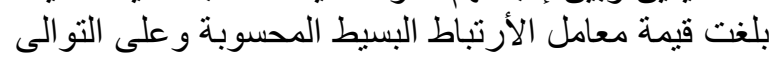

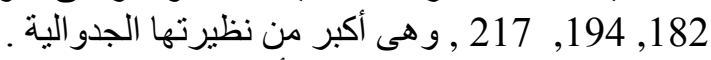

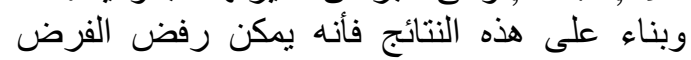

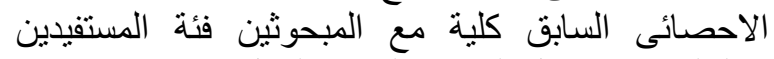

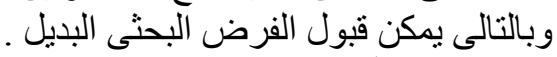

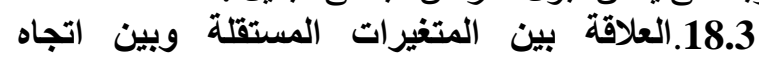
المبحوثين من فئة غير الميرات المشتركين في نظين نظام التأمينات الاجتماعين

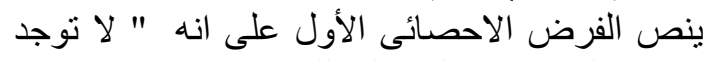

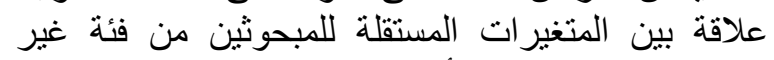

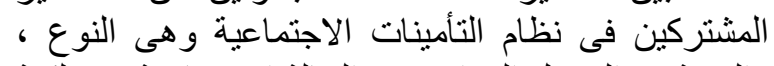

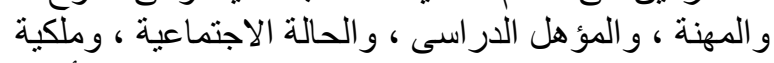

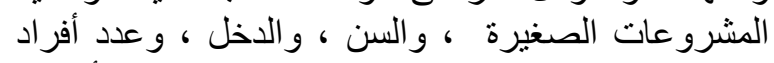

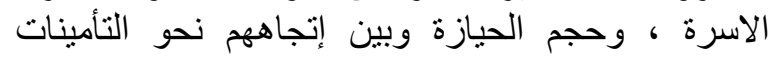

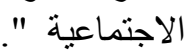

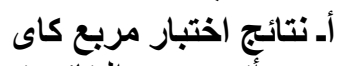

أتضخح من النتائج في (جدول

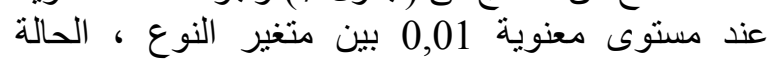

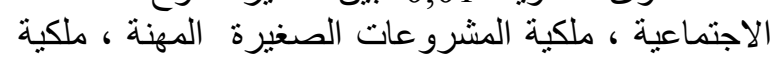

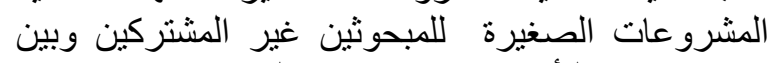

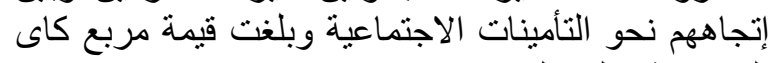

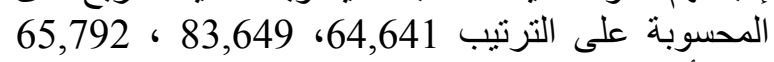
و هى أكبر من نظيرتها الجدو التبابة الية.

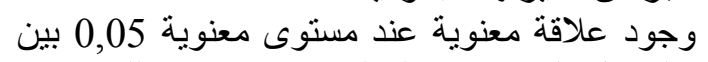
متغير المؤهل الدراسى ، الحالة الاجتماعية للئية 


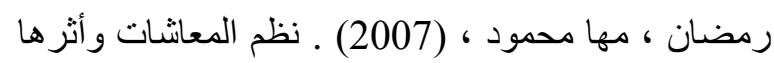
على الاقتصاد المصري، مجلد البحوث المران المالية،

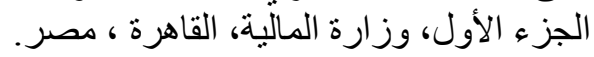

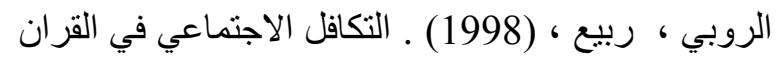

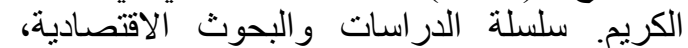

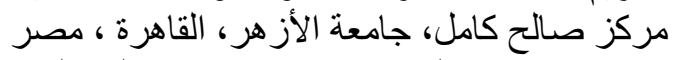

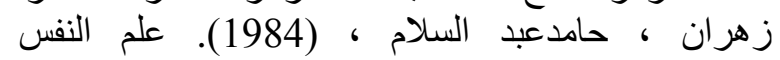

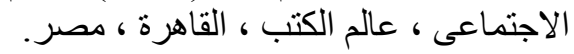

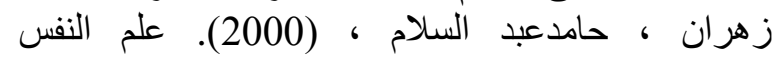
الاجتماعى ، الطبعة الثانية ، عالم الكتاب ، القاهرة

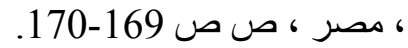

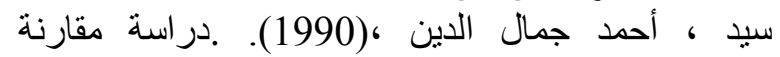

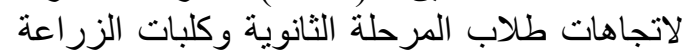

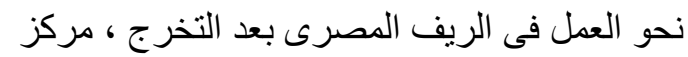

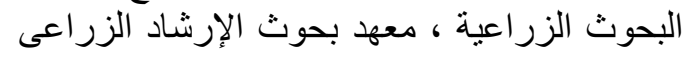
و التمية الريفية ، الجيزة ، مصر- نشرة بحثية رقم الأرمان

السيد ، هدى مجدى ، (1998). التأمينات الاجنماعية

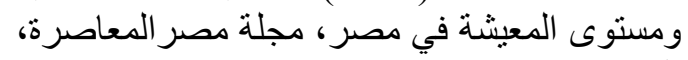
العدد 499، يناير . العبن.

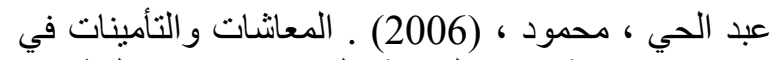

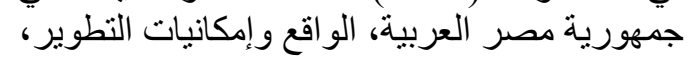

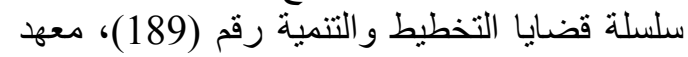
التخطبط القومي، القاهرة .

عبد العزيز ، سامية إبراهيخ ، الفاهرة (2007) ـ ـ إصلاح نظام

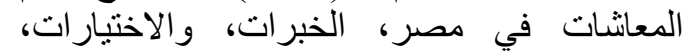

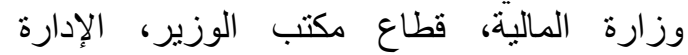
المركزية لمركز المعلومات و التوثيق، القاهرة ، الإدارة

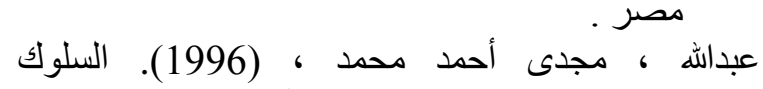
الاجتماعى ودينامياته محاولة تفسيرية الاية ، دار المعرفة الجامعية ، الإسكندرية .

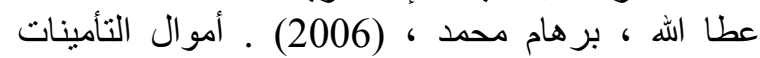
الاجتماعية إلى أين، كتاب الأهرام الاقتصادي،

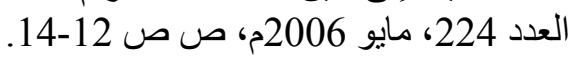

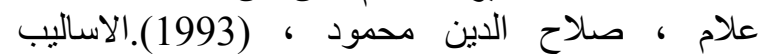

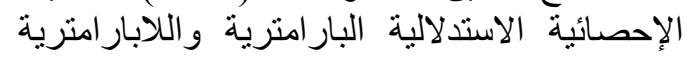

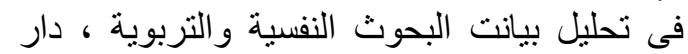

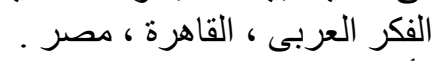

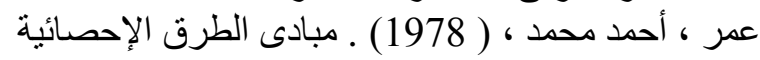

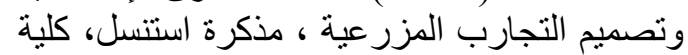

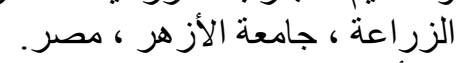

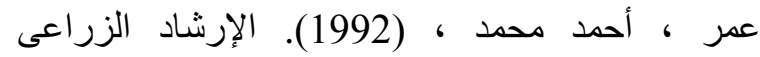

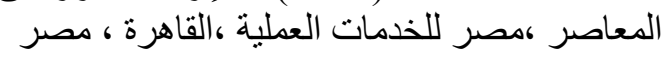

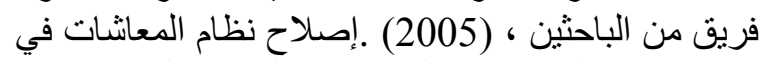

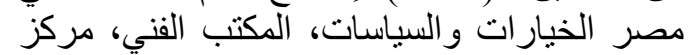
المعلومات ودعم اتخاذ القرار، مجلس الفئ رئاسة

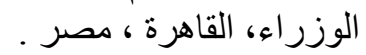

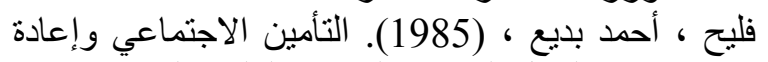

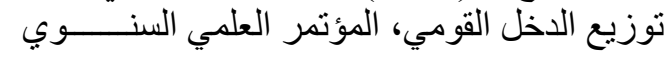

حيث أن المستثمر فى هذا القطاع يحقق أرباح صافية تعادل عشرة أمثال رأس المال المدفوع تقريباً.

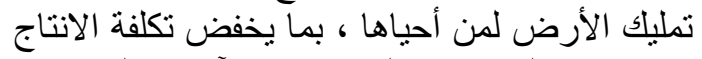

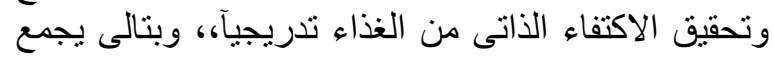
الصندوق بين تحقيق المصالح العامة و الدصالح الذائ الخاصية.

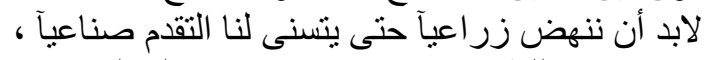

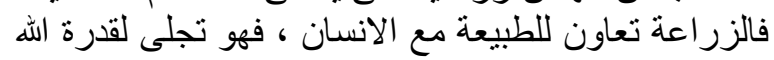

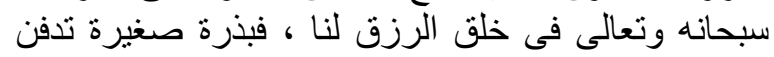

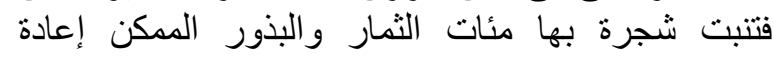

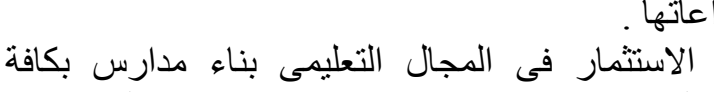

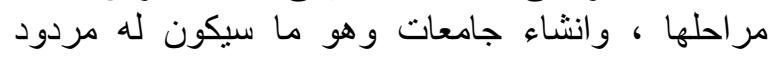

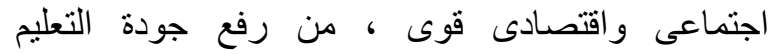

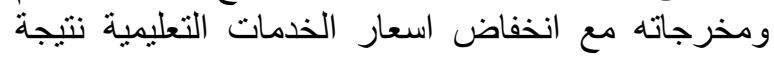

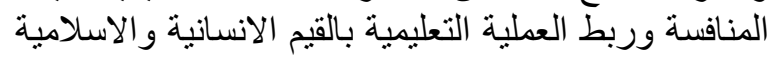
ويترتب عليه تعميق الانتماء والمواطنة بلنة بالاضافة للئنة للأرباح

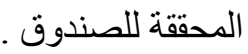

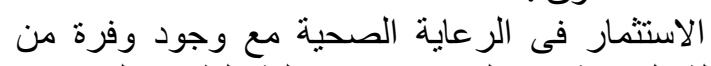

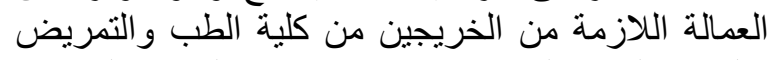

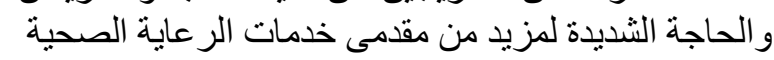

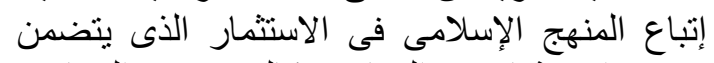

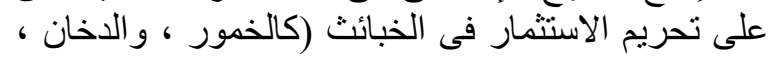

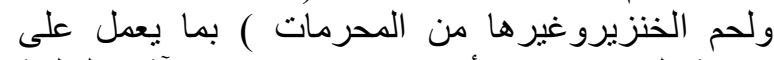
سلامة المجتمع من الأمراض ونير وغير ها من الآثار السلبية

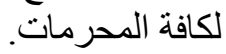

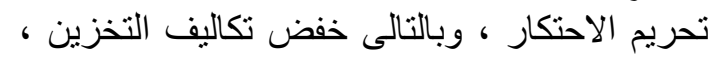

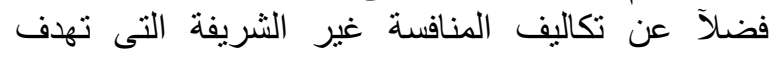

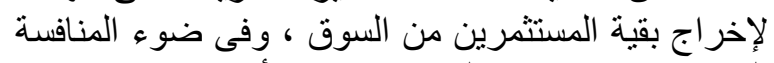

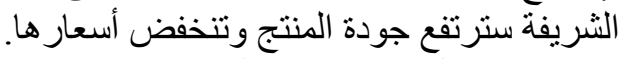

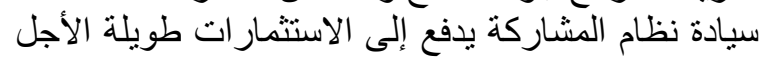

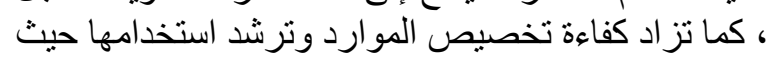
لا يقدم الممول المشاركأك أمواله إلا لأكثر المستثمرين جدية ونجاحاً. كفالة المدينين والغارمين و المشروعات الخاسرة من خلال صندوق المساعدات الاجتماعية .

\section{4 - 2 - المراجع العربية}

إبراهيم ،أمنية خيرى، (2006). الاستدامة المالية لنظام

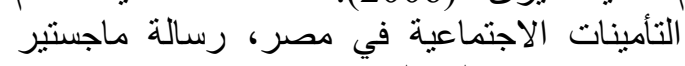

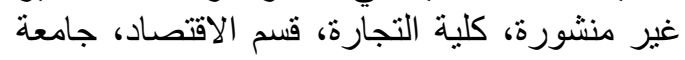

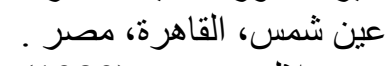

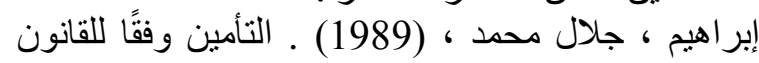

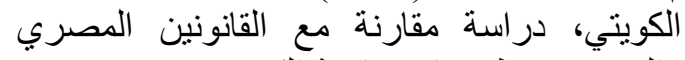

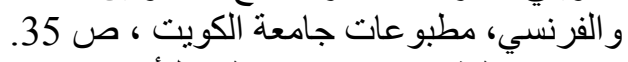

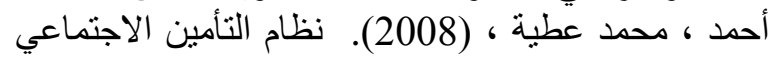
المصري ما بين التطور و التقليد للتجارب التين الأدولية. مركز الدراسات السياسية والاستر اتيجية، مؤسسة لإنة

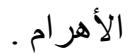




\section{REFERENCES}

Ghosh B.N. (1985). Scientific Method and Social Research Sterling Publishers Private Limited, New york, USA.

http //www.adb.org/social protection defult.asp http // www.columbia.edu/xs

23/papers/pads/pensions.pdf.

Sala I.M. (1995). A ppositive theory of social security. Yale University, USA. November 23, p4.

Social protection adb "asian development bank".

Social Safety net, Wikipedia, The Freeneyelopedia-

h//en.wikipedia.ongiwikisocial-safety-net.

Somers B. A. (1982). The effects of public pension plans in Canada: a theoretical and empirical analyses. Thesis Submitted to the Faculty of Graduate Sudies and Research in Partial Fulfillment of the Requirements for the degree of doctor of philosophy in economics, department of economics, McGill University. Monterial, Canada, December

Unesco ., ( 1984). project fvalution problems of methodology scoitzerlend .

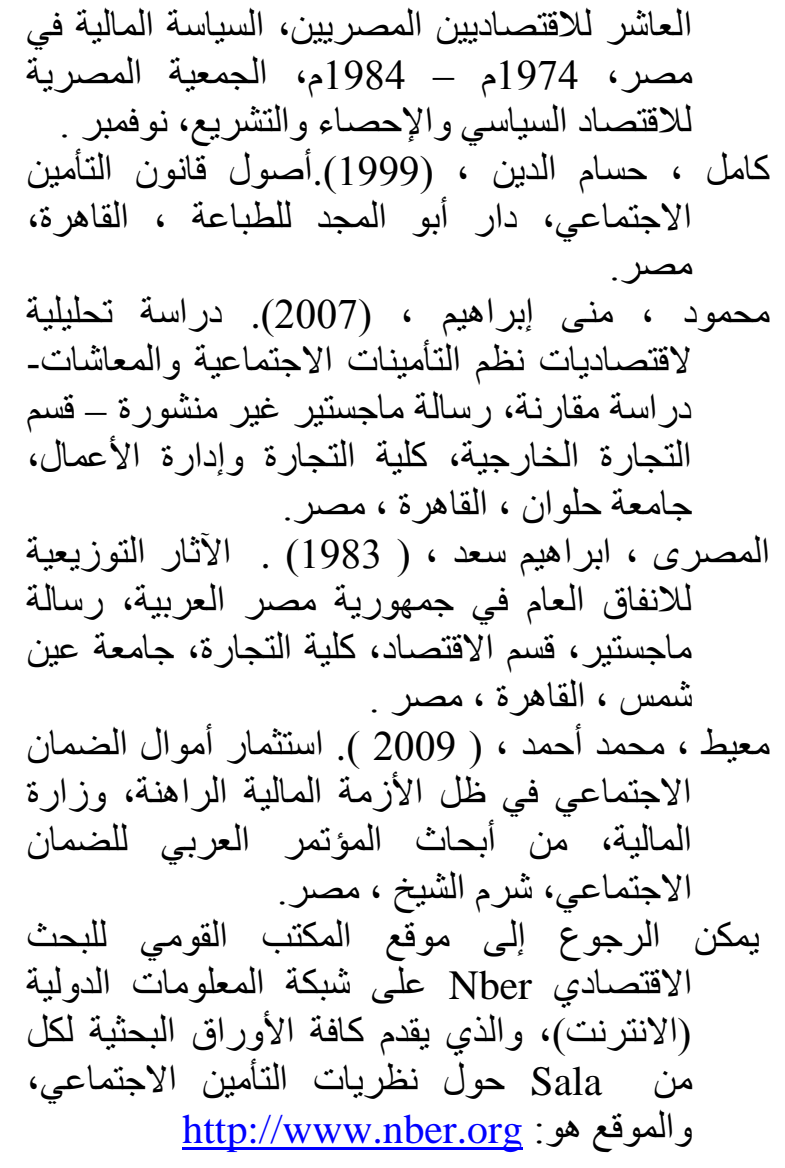

العانشر للاقتصاديين المصريين، السياسة المالية في

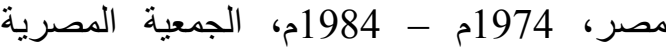

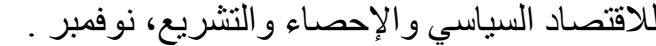

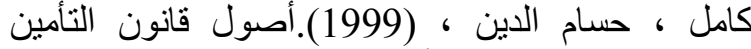
الاجتماعي، دار أبو المجد للطباعة ، القاهرة، التانئ

محمود ، منى إبراهيم ، القيات (2007). دراسة تحليلية لاقتصاديات نظم التأمينات الاجتماعية و المعانثاتـ

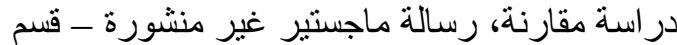
التجارة الخارجية، كلية التجارة وإدارة إدارة الأعمال، المصرى ، ابر اهيم سعد ، ( 1983) ، الفاهة ـ ـ الآثار التوزيعية للانفاق العام في جمهورية مصر الهرية العربية، رسالة التارية ماجستير، قسم الاقتصاد، كلية التجارة، جامعة عين التربة معيط ، محمد أحمد ، ( 2009 ) ). استثمار أموال الضمان الزمان

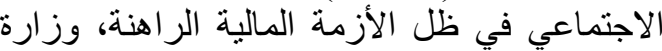

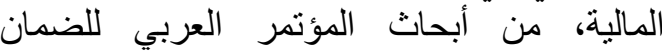
يمكن الرجوع إلى موقع المكتب المئ القومي للبحث

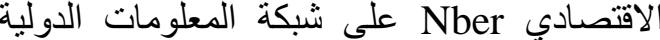

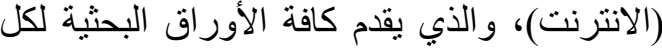
والموقع هو: http://www.nber.org 